\title{
Regulation of Hematopoiesis and Hematological Disease by TGF- $\beta$ Family Signaling Molecules
}

\author{
Kazuhito Naka ${ }^{1}$ and Atsushi Hirao ${ }^{2}$ \\ ${ }^{1}$ Department of Stem Cell Biology, Research Institute for Radiation Biology and Medicine, Hiroshima \\ University, Minami-ku, Hiroshima 734-8553, Japan \\ ${ }^{2}$ Division of Molecular Genetics, Cancer Research Institute, Kanazawa University, Kanazawa, Ishikawa \\ 920-1192, Japan \\ Correspondence: ahirao@staff.kanazawa-u.ac.jp
}

\begin{abstract}
Throughout the lifetime of an individual, hematopoietic stem cells (HSCs) maintain the homeostasis of normal hematopoiesis through the precise generation of mature blood cells. Numerous genetic studies in mice have shown that stem-cell quiescence is critical for sustaining primitive long-term HSCs in vivo. In this review, we first examine the crucial roles of transforming growth factor $\beta$ (TGF- $\beta$ ) and related signaling molecules in not only regulating the well-known cytostatic effects of these molecules but also governing the selfrenewal capacity of HSCs in their in vivo microenvironmental niche. Second, we discuss the current evidence indicating that TGF- $\beta$ signaling has a dual function in disorders of the hematopoietic system. In particular, we examine the paradox that, although intrinsic TGF- $\beta$ signaling is essential for regulating the survival and resistance to therapy of chronic myelogenous leukemia (CML) stem cells, genetic changes that abrogate TGF- $\beta$ signaling can lead to the development of several hematological malignancies.
\end{abstract}

$T^{T}$ he hallmarks of hematopoietic stem cells (HSCs) are their capacity to give rise to all lineages of mature hematopoietic cells, and their ability to reproduce themselves, a property known as self-renewal. In vivo, these HSC activities occur in a bone marrow (BM) niche, which provides a comfortable microenvironment for HSCs and maintains their stem-cell quiescence until their activities are required (Suda et al. 2005; Lo Celso and Scadden 2011; Wang and Wagers 2011; Morrison and Scadden 2014). Several intrinsic and extrinsic factors exert cytostatic effects on HSCs in vivo (Orkin and Zon 2008; Zon 2008; Pietras et al. 2011). Specifically, transforming growth factor $\beta$ (TGF- $\beta$ ) signaling has an essential function in supporting the mainte- nance of the self-renewal capacity of HSCs, a function that varies with tissue context (Söderberg et al. 2009; Blank and Karlsson 2015). We first focus on the roles of TGF- $\beta$ family molecules in determining cell fate and hematopoietic lineage selection, and in maintaining the selfrenewal capacity of normal HSCs in vivo in a cell-context-dependent manner.

\section{TGF- $\beta$ AND BONE MORPHOGENETIC PROTEIN (BMP) SIGNALING IN NORMAL HEMATOPOIESIS \\ TGF- $\beta$ Signaling in HSCs}

The mammalian TGF- $\beta$ protein family is encoded by 33 genes, and comprises evolution-

Editors: Rik Derynck and Kohei Miyazono

Additional Perspectives on The Biology of the TGF- $\beta$ Family available at www.cshperspectives.org

Copyright (C) 2017 Cold Spring Harbor Laboratory Press; all rights reserved; doi: 10.1101/cshperspect.a027987

Cite this article as Cold Spring Harb Perspect Biol 2017;9:a027987 
arily conserved and highly homologous polypeptides, which act as homo- or heterodimers to exert their functions as cytokines. The binding of a TGF- $\beta$ family ligand to two pairs of cell-surface serine-threonine kinase receptors, known as the type II and type I receptors, activates TGF- $\beta$ family signal transduction (Massagué 2000; Feng and Derynck 2005; Derynck and Miyazono 2007). In the case of TGF- $\beta$, this pathway is activated by the engagement of T $\beta$ RII by a TGF- $\beta$ ligand, which promotes recruitment and phosphorylation of TRRI (also known as activin receptor-like kinase 5 [ALK-5]) (Heldin and Moustakas 2016). The tetrameric T $\beta R I I-T \beta R I$ receptor complex is then activated and, in turn, phos- phorylates and activates Smad2 and Smad3 proteins (Fig. 1).

It had been expected that a genetic approach might clarify the exact functions and biological significance of TGF- $\beta$ in the control of HSCs in vivo. However, the required experiments were initially difficult because null mutant mice with inactivated $T g f b 1$, encoding TGF- $\beta 1$ (Shull et al. 1992; Kulkarni et al. 1993; Letterio et al. 1996; Yaswen et al. 1996), Tgfbr1, encoding T $\beta R I$ (Larsson et al. 2001), or Tgfbr2, encoding TßRII (Oshima et al. 1996; Leveen et al. 2002) genes succumbed to early embryonic lethality caused by abnormalities in vascular endothelial cells or angiogenesis, or a massive inflammatory and/or autoimmune response. This problem

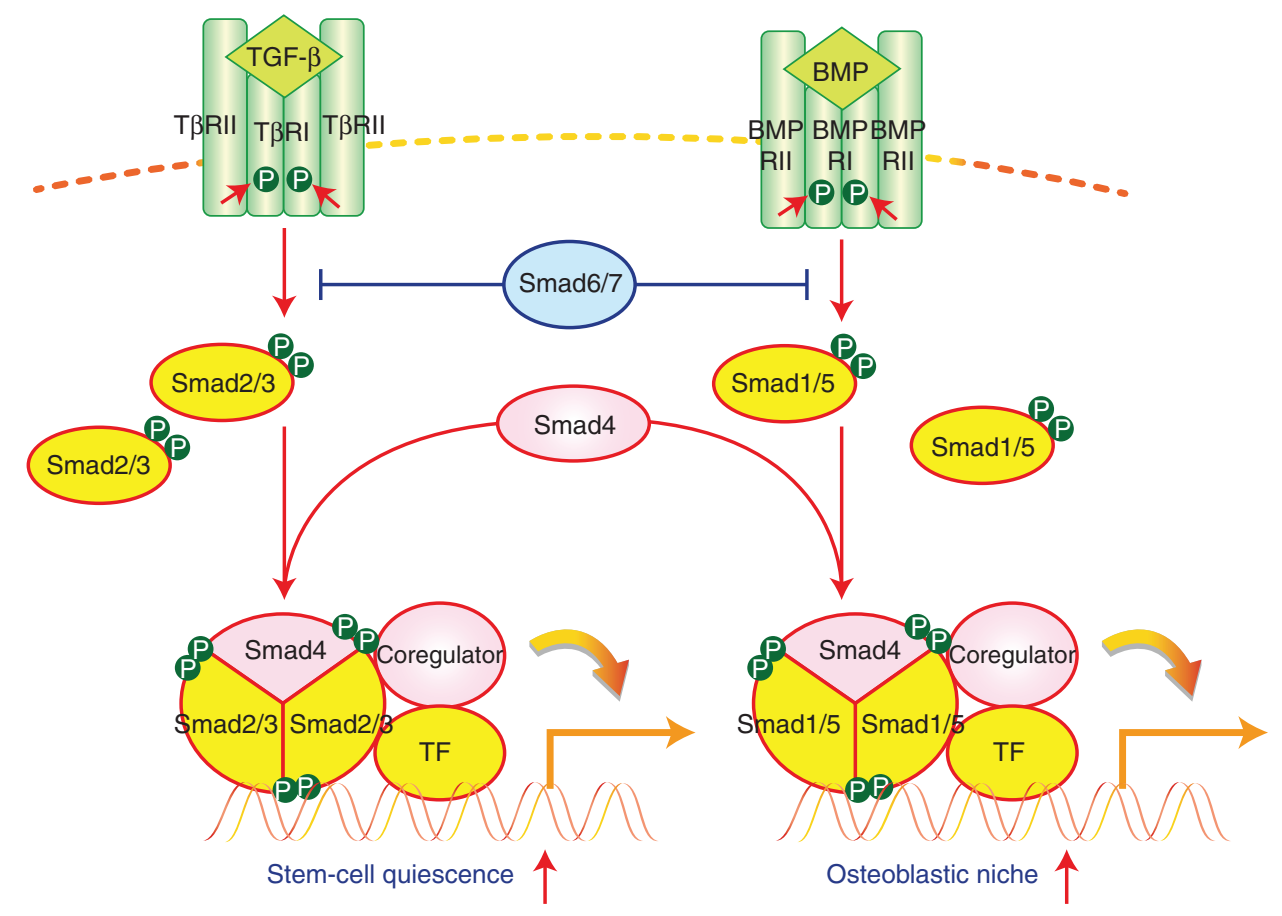

Figure 1. Transforming growth factor $\beta$ (TGF- $\beta$ ) and bone morphogenetic protein (BMP) signal transduction. Binding of TGF- $\beta$ to dimeric T $\beta$ RII enables ligand binding to dimeric T $\beta$ RI and stimulates the kinase activity of T $\beta R I$. In Smad-mediated TGF- $\beta$ signal transduction, T $\beta R I$ phosphorylates cytoplasmic Smad2 and Smad3, which, following dissociation from T $\beta R I$, interact with Smad4. The trimeric complex of two receptor-activated Smad2 and/or Smad3 with one Smad4 then enters the nucleus, where it interacts with DNA-binding transcription factors (TFs) and coregulators at regulatory sequences of target genes, in a gene- and cell-contextdependent manner. BMP signaling operates in parallel and similarly to TGF- $\beta$ signaling. In response to the binding of BMP ligands to the heteromeric receptor complex of BMPRII and BMPRI transmembrane kinases, receptor-activated Smad1 and Smad5 associate with Smad4 and translocate into the nucleus to activate or repress BMP target gene transcription. 
has been solved by investigating the self-renewal capacity of HSCs in $T g f b 1^{-/-}$neonates before the onset of inflammatory disease. This research showed that the HSC pool was decreased in size in 8- to 10-day-old $\mathrm{Tg} f b 1^{-/-}$neonates, when compared with control mice (Capron et al. 2010). Furthermore, HSCs isolated from 8- to 10-day-old $\mathrm{Tgfb} 1^{-/-}$mice showed an attenuated self-renewal capacity following transplantation into recipient animals, with no signs of inflammatory or autoimmune disease (Capron et al. 2010). In addition, in comparison with $T g f b 1^{+/+}$cells, $T g f b 1^{-/-}$fetal liver cells isolated at embryonic day 14 (E14), thus containing primitive HSCs, failed to reconstitute hematopoietic cells in transplanted recipients (Capron et al. 2010). In the same vein, although conditional disruption of the Tgfbr1 gene has no significant effect on the quiescence and maintenance of the HSC pool (Larsson et al. 2003, 2005), conditional Tgfbr2-deficient mutants show defects in HSC quiescence and BM repopulating capacity following transplantation into wild-type recipient mice (Yamazaki et al. 2011). Collectively, these genetic studies show that TGF- $\beta$ signaling is a major regulator of HSC function in vivo.

Three highly conserved TGF- $\beta$ ligands, TGF- $\beta 1,-\beta 2$, and $-\beta 3$, are encoded by different genes. TGF- $\beta 1$ is a potent negative regulator of hematopoietic progenitor cells (Ohta et al. 1987; Ottmann and Pelus 1988). Indeed, when HSCs are pretreated ex vivo with TGF- $\beta 1$ before transplantation into recipient mice, the in vivo long-term reconstitution ability of these HSCs is attenuated (Soma et al. 1996). TGF- $\beta 3$ also suppresses the colony-forming capacity of human BM mononuclear cells in vitro, but TGF$\beta 2$ increases this ability in these cells as well as in murine hematopoietic progenitor cells (Jacobsen et al. 1991; Langer et al. 2004). Notably, the proportion of Lineage ${ }^{-} \mathrm{Scal}^{+} \mathrm{cKit}^{+}$(LSK) cells in $\mathrm{Tg} f b 2^{+/-}$mice is decreased compared with that in wild-type mice, indicating that TGF- $\beta 2$ is a positive regulator of the HSC population. In addition, $T g f b 2^{+/-}$LSK cells from adult mice show reduced self-renewal capacity on serial transplantation (Langer et al. 2004). Thus, although TGF- $\beta 1,-\beta 2$, and $-\beta 3$ induce distinct responses in HSCs, their activities determine the hematopoietic cell fate and maintain the self-renewal ability of HSCs in their in vivo microenvironmental niche.

\section{Smad Signaling in HSCs}

The Smad protein family consists of eight members that are classified by function. Smad1, 2, 3, 5 , and 8 are "receptor-activated Smads" (RSmads), whereas Smad4 is the "common mediator Smad" (co-Smad) that associates and cooperates with R-Smads, and Smad6 and 7 are "inhibitory Smads" (I-Smads) that inhibit R-Smad activation and functions (Derynck and Zhang 2003; Massagué et al. 2005; Hata and Chen 2016). Smad 1, 5, and 8 primarily mediate BMP signaling (see below), whereas Smad2 and 3 mediate TGF- $\beta$ and activin signal transduction. R-Smads are activated by carboxy-terminal phosphorylation by the TGF- $\beta$ or BMP type I receptor kinases, and their activities are further controlled through phosphorylation by other kinases (Derynck and Zhang 2003; Massagué 2012; Hata and Chen 2016; Heldin and Moustakas 2016). In the canonical TGF- $\beta$ and BMP pathways, the T $\beta R I$ or BMP type I receptor (BMPRI) kinases directly phosphorylate Smad proteins at their conserved carboxy-terminal Ser-Ser-X-Ser motif. This phosphorylation is required for ligand-induced Smad translocation into the nucleus and for interactions with partner transcription factors. In addition to the carboxy-terminal phosphorylation motif, R-Smads contain two conserved "Mad homology" domains, $\mathrm{MH} 1$ and $\mathrm{MH} 2$, which are connected by a linker region (Derynck and Zhang 2003; Massagué et al. 2005; Hata and Chen 2016). Phosphorylation of this linker region is thought to be critical for regulating R-Smad activity in a cell-context-dependent manner (Wrighton et al. 2009).

Genetic studies in mice have elucidated roles of Smad proteins in vivo. Smad4 ${ }^{-/-}$mice die at E6.5 due to a failure in gastrulation and abnormalities in the visceral endoderm, indicating that Smad4 is required for early embryogenesis (Sirard et al. 1998; Yang et al. 1998). Smad2 ${ }^{-/-}$ mice do not survive early embryogenesis due to 
abnormalities in their anterior-posterior polarity (Nomura and Li 1998; Waldrip et al. 1998; Weinstein et al. 1998). In contrast, although viable, Smad $3^{-1-}$ mice show functional defects in T cells (Datto et al. 1999; Yang et al. 1999). Both B cells and T cells express Smad3 (Datto et al. 1999). T cells isolated from Smad3 $^{-/-}$mice, however, show an activated phenotype in vivo, and are not inhibited by treatment with TGF- $\beta$, indicating a vital role of Smad3 in regulating the T-cell-mediated adaptive immune system in adult mice (Datto et al. 1999; Yang et al. 1999). To examine the function of Smad3 in hematopoiesis in vitro, BM cells from the femurs and tibias of $\mathrm{Smad3}^{+/+}, \mathrm{Smad}^{+/-}$, and Smad3 ${ }^{-/-}$mice were cultured long term in vitro (Epperly et al. 2005). The nonadherent cell cultures established from Smad3 ${ }^{-1-}$ mice showed more cells capable of forming colonies than those from Smad3 $3^{+/+}$or Smad3 ${ }^{+/-}$mice (Epperly et al. 2005). These results suggest that suppression of Smad3 signaling contributes to sustain long-term hematopoiesis in vitro.

The roles of the different phosphorylation sites of the Smad linker regions are not fully defined. Serine and threonine residues in the linker region can be phosphorylated by several kinases, including the cyclin-dependent kinases CDK8 and CDK9, glycogen synthase kinase 3 (GSK3), and the mitogen-activated protein kinases (MAPKs), that is, extracellular signal-regulated kinase (Erk) MAPK, p38 MAPK, and c-Jun amino-terminal kinase (JNK) (Kretzschmar et al. 1999; Matsuura et al. 2004; Kamaraju and Roberts 2005; Liu 2006; Alarcón et al. 2009; Millet et al. 2009; Wang et al. 2009; Wrighton et al. 2009; Massagué 2012; Matsuzaki 2013). Although the carboxy-terminal phosphorylation of Smad3 by the type I receptor may be required for linker phosphorylation, T $\beta R I$ itself does not phosphorylate residues in the linker region (Wang et al. 2009). However, TGF- $\beta$ receptor signaling enables activation of the MAPKs that can phosphorylate the Smad3 linker region. In response to engagement of the T $\beta$ RII-T $\beta R I$ complex by TGF- $\beta$ ligand, the TRAF6-TAK1 complex activates p38 MAPK and JNK signaling, and the Ras-Raf pathway activates Erk MAPK signaling (Xu et al. 2009). Thus, TGF- $\beta$ signaling appears to both directly and indirectly regulate Smad activities. The importance of the Smad3 linker region phosphorylation has been revealed in studies using expression of a Smad3 with a linker region that is not phosphorylated. Expression of this Smad3 mutant enhances the epithelial-mesenchymal transition (EMT) induced by TGF- $\beta$, and promotes the metastatic activity of breast carcinoma cells in vivo (Bae et al. 2014).

Overexpression of Smad4 was shown to reduce the regenerative capacity of human cord blood-derived HSCs in vivo (Rörby et al. 2012). Conversely, enforced expression of the inhibitory Smad7, which suppresses TGF- $\beta$ - and BMPinduced Smad signal transduction, enhances the HSC self-renewal capacity in vivo (Blank et al. 2006). These results suggest that Smad signaling provides a repressive force necessary for the maintenance of HSC function. Paradoxically, however, HSCs isolated from conditional Smad4-deficient mice show a reduced self-renewal capacity following transplantation into recipient animals (Karlsson et al. 2007). Thus, although the TGF- $\beta$-Smad pathway is involved in HSC maintenance in vivo, fine-tuning of this pathway's intrinsic activity is crucial for the control of HSC self-renewal capacity (Yamazaki et al. 2011).

\section{Activin Signaling in Erythropoiesis}

Activins and inhibins, which also belong to the TGF- $\beta$ family, play fundamental roles in early mouse embryogenesis and terminal differentiation of hematopoietic cells. Activins bind to the type II receptors ActRIIA and ActRIIB and the type I receptors ALK-4/ActRIB and ALK-7/ ActRIC, and activate Smad2 and Smad3 for intracellular signaling (Namwanje and Brown 2016). In particular, activin A, also called "erythroid differentiation factor," plays an important role in erythropoiesis. Activin A was first identified as a factor sustaining the erythroid differentiation of mouse Friend erythroleukemic cells (Eto et al. 1987). Indeed, in vivo administration of activin A to mice increases erythroid burst-forming units (BFU-E) and 
erythroid colony-forming units (CFU-E) in BM cultures established from anemic and healthy mice (Shiozaki et al. 1989). Treatment of primary human total BM cells or human $\mathrm{CD} 34^{+}$progenitor cells in vitro with activin $\mathrm{A}$ induces the expression of the erythropoietin receptor and hemoglobin, and promotes the proliferation of erythroid progenitors (Yu et al. 1987; Maguer-Satta et al. 2003). In the human K562 erythroleukemia cell line, activin A regulates hemoglobin synthesis and expression of $\alpha$-globin and $\zeta$-globin (Huang et al. 2004, 2006); thus, activin signaling is vital for the erythropoiesis.

Another activin-related ligand that controls erythropoiesis is growth and differentiation factor-11 (GDF-11, also known as BMP-11), a TGF- $\beta$ family ligand that acts through type II receptors ActRIIA and/or ActRIIB and type I receptors ActRIB and/or T $\beta R I$, and downstream Smad2 and Smad3 (Heldin and Moustakas 2016), and thus drives erythroid cell maturation. Two fusion proteins, in which the receptor extracellular domains are fused to a dimerizing immunoglobulin (Ig) Fc fragment, were used as an "activin ligand trap," thus enabling sequestration of activin and related ligands (Iancu-Rubin et al. 2013; Suragani et al. 2014). ACE-011 and ACE-536 consist of the extracellular domain of human ActRIIA and ActRIIB, respectively, fused to the human IgG Fc domain, and their mouse counterparts are called RAP-011 and RAP-536, respectively. Administration in vivo of ACE-011 and ACE-536 to wild-type mice increases erythrocyte numbers, hemoglobin concentration, and hematocrit levels in a dose-dependent manner, indicating that they promote erythropoiesis (Suragani et al. 2014; Langdon et al. 2015). Importantly, ACE-536, containing the extracellular domain of ActRIIB modified to reduce activin binding, binds to GDF-11 and inhibits GDF11-induced Smad2 and Smad3 signaling, thus suppressing erythropoiesis (Suragani et al. 2014). Administration of ACE-011 or ACE-536 also restores normal erythrocyte parameters in rat anemia models and a mouse model of anemia, based on transgenic expression of iron-restricted hepcidin antimicrobial peptide, or a mouse model of myelodysplastic syndrome (MDS), based on
NUP98-HOXD13 expression (Iancu-Rubin et al. 2013; Suragani et al. 2014; Langdon et al. 2015). These findings suggest that sequestration of the GDF-11 ligand by ACE- 011 or ACE-536, and consequently preventing GDF-11 binding to ActRIIA and ActRIIB, might have a therapeutic benefit for patients with anemia, including those suffering from $\beta$-thalassemia, DiamondBlackfan anemia (DBA), or MDS. This approach might also relieve the anemia induced in cancer patients by chemotherapy (Suragani et al. 2014; Raftopoulos et al. 2016).

\section{BMP Signaling in HSCs}

As noted above, Smad1 and Smad5 mediate the BMP signaling pathway (Fig. 1). Genetic studies have indicated that conditional mutant mice disrupted in either only the Smad5 gene, or both the Smad1 and Smad5 genes, have no obvious defects in HSC functions (Singbrant et al. 2006, 2010). Thus, BMP signaling is dispensable for intrinsic HSC maintenance in vivo. However, conditional disruption in mice of the Bmprla gene that encodes the BMPRIA receptor, also known as ALK-3, increases the number of osteoblasts in the BM, which results in expansion of the HSC niche in BM (Zhang et al. 2003). Consequently, this niche enlargement enhances HSC self-renewal and the size of the HSC pool. Thus, BMP signaling indirectly controls the HSC numbers in adult mice. Additionally BMP signaling is directly implicated in determining the HSC fate in vivo, as discussed below.

\section{TGF- $\beta$ and BMP Signaling during Lineage-} Biased Commitment of HSCs

The traditional view of hematopoiesis is based on a simple hierarchy in which all HSCs have the same ability to commit their progeny to either myeloid or lymphoid differentiation. However, the most primitive long-term self-renewing HSCs can be subdivided into three cell types based on their differentiation capacity, that is, myeloid-biased (My)-HSCs, lymphoid-biased (Ly)-HSCs, and myeloid- and lymphoid-balanced (Bala)-HSCs (Fig. 2) (Müller-Sieburg et al. 2002, 2004; Sieburg et al. 2006; Cho 
K. Naka and A. Hirao

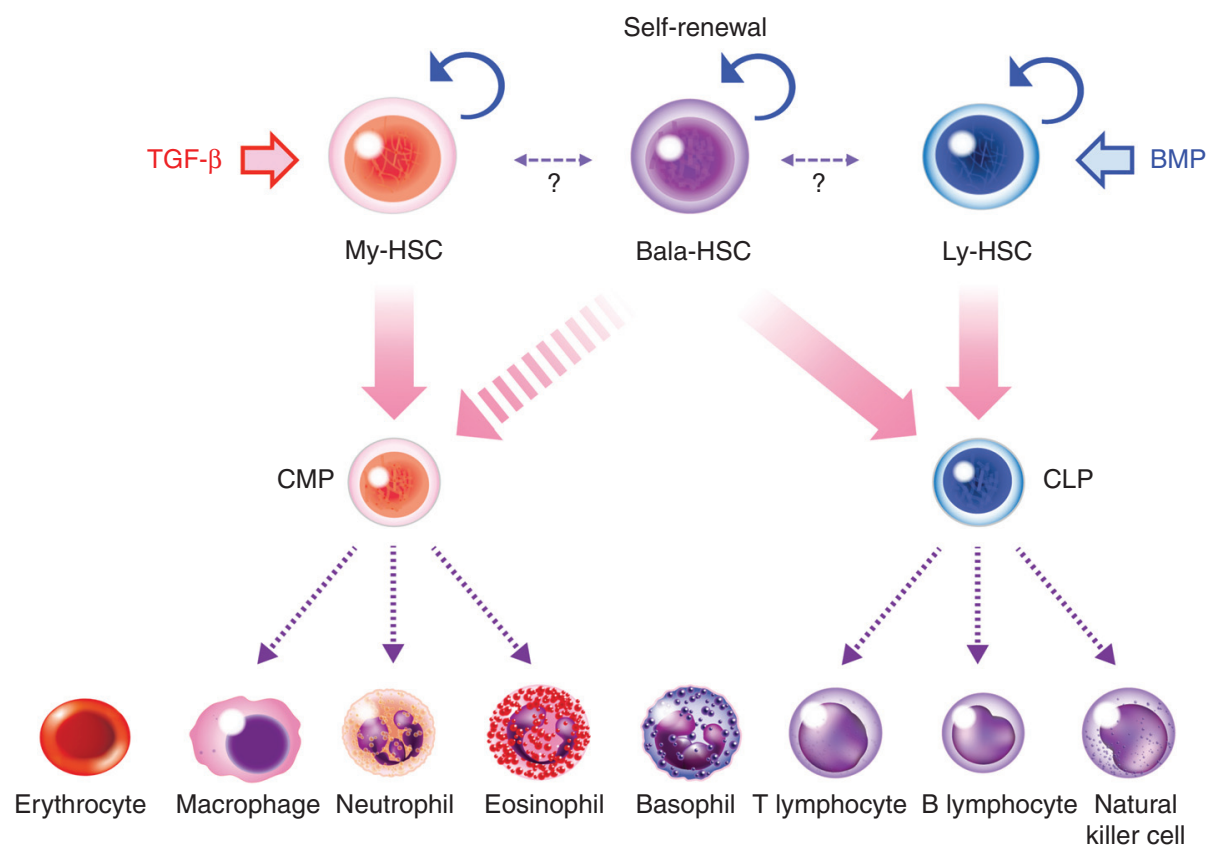

Figure 2. Hematopoietic hierarchy and transforming growth factor $\beta$ (TGF- $\beta$ ) and bone morphogenetic protein (BMP) signaling. Hematopoietic stem cells (HSCs) can self-renew and give rise to all mature hematopoietic cell lineages. Total HSCs can be classified into myeloid-biased (My)-HSCs, lymphoid-biased (Ly)-HSCs, and myeloid- and lymphoid-balanced (Bala)-HSCs. My-HSCs predominantly generate common myeloid progenitors (CMPs), whereas Ly-HSCs give rise to common lymphoid progenitors (CLPs). These CMPs and CLPs go on to generate most mature hematopoietic cell types, as indicated. Within the in vivo BM microenvironmental niche, Ly-HSCs are supported mainly by BMP signaling, whereas My-HSCs are regulated mainly by TGF- $\beta$ signaling.

et al. 2008; Schroeder 2010; Geiger et al. 2013; Pietras et al. 2015). My-HSCs give rise to more myeloid than lymphoid cells, and Ly-HSCs generate many lymphoid cells but few myeloid cells. Although Bala-HSCs can differentiate into both lymphoid and myeloid cells, they mostly differentiate along the lymphoid lineage.

TGF- $\beta 1$ signaling specifically supports MyHSC proliferation (Challen et al. 2010). After separating the total murine HSC population by cell sorting into My-HSCs and Ly-HSCs, using Hoechst dye efflux combined with detection of traditional stem-cell markers of HSCs (i.e., the LSK cell population), My-HSCs tend to be enriched in the lower side population of LSK cells, whereas Ly-HSCs are enriched in the upper side population of LSK cells. Both side populations maintain their My-HSC and Ly-HSC populations during serial transplantation in mice in vivo, and during physiological aging, whereas aged total HSCs tend to commit to My-HSCs rather than Ly-HSCs. Ly-HSCs and My-HSCs show distinct responses to TGF- $\beta 1$. Treatment in vitro with a low concentration $(1 \mathrm{ng} / \mathrm{ml}$ ) of TGF- $\beta 1$ stimulates My-HSC proliferation but suppresses Ly-HSC proliferation, and decreases the proportion of $\mathrm{G}_{0}$ phase quiescent cells among My-HSCs but not Ly-HSCs (Challen et al. 2010). In vivo, administration of TGF- $\beta 1$ to mice with transplanted MyHSCs increases the proliferation of donor MyHSCs and myeloid progenitors, but has no effect on Ly-HSC differentiation or proliferation (Challen et al. 2010). To understand the molecular basis of these distinct responses to TGF- $\beta 1$, gene expression patterns were assessed in $\mathrm{My}$ - 
HSCs and Ly-HSCs treated with TGF- $\beta 1$. The levels of mRNAs encoding the $16^{\text {Ink4a, }}$ $\mathrm{p} 21^{\text {Waf1/Cip1 }}$, and $\mathrm{p} 57^{\mathrm{Kip} 2} \mathrm{CDK}$ inhibitors were comparable, but the levels of mRNAs for p $18^{\text {Ink } 4 \mathrm{c}}$ and $\mathrm{p} 19^{\mathrm{Ink} 4 \mathrm{~d}}$, which suppress the $\mathrm{G}_{0} /$ $\mathrm{G}_{1}$ transition, were dramatically decreased in TGF- $\beta 1$-treated My-HSCs, when compared with Ly-HSCs. Thus, TGF- $\beta 1$ induces changes in gene expression that selectively regulate $\mathrm{My}-$ HSC functions (Challen et al. 2010). Furthermore, although mouse genetic studies show that dysregulation of HSC quiescence compromises their long-term maintenance in vivo (see below), short-term TGF- $\beta 1$ stimulation that transiently nudges My-HSCs to enter the cell cycle may be needed to sustain the repopulation capacity of these cells.

How BMP signaling contributes to lineagebiased commitment in HSCs has also been explored. Using transgenic mice with a BMP-responsive GFP reporter ( $B R E-G F P$ mice), murine fetal liver and adult BM HSCs were shown to contain BMP-activated and non-BMP-activated cells (Crisan et al. 2015). In E14 fetal liver, longterm HSCs, that is, CD $150^{+} \mathrm{CD} 48^{-}$LSK cells, contain a higher proportion of BMP-activated cells $(73 \%)$ than nonactivated cells (27\%), whereas in adult BM of these mice the majority of long-term HSCs were non-BMP-activated cells (92\%). These data suggest that BMP signaling is attenuated in adult BM HSCs due to factors affected by age and the in vivo microenvironment (Crisan et al. 2015). Analysis of the celllineage differentiation of these BMP-activated and nonactivated HSCs in transplanted mice revealed that the capacity of adult BM HSCs to generate mature hematopoietic cell lineages depends on the activation of BMP signaling. BMPactivated adult BM HSCs produce mainly BalaHSCs and Ly-HSCs, whereas nonactivated HSCs give rise to My-HSCs and Ly-HSCs (Crisan et al. 2015). RNA-sequencing analysis also revealed that BMP-activated HSCs show increased expression of prolymphoid genes, such as Flt3 and $I k z f 1$, compared with nonactivated HSCs. Thus, a prolymphoid transcriptional program is elaborated in BMP-activated HSCs, and the BMP pathway preferentially sustains lymphoid-biased commitment of HSCs.
Collectively, these findings suggest that LyHSCs are mainly regulated by BMP signaling, whereas My-HSCs are mainly controlled by TGF- $\beta$ signaling. The evidence is thus accumulating that the TGF- $\beta$ and BMP signaling pathways differentially control lineage-biased commitment of HSCs within the in vivo BM microenvironment (Fig. 2).

\section{TGF- $\beta$ Signaling during HSC Aging}

Because HSCs are responsible for hematopoiesis during an animal's entire lifetime, their genomic integrity needs to be preserved to avoid hematological dysfunction or malignancy during aging. However, HSCs of aged individuals are susceptible to DNA damage and replication stress (Beerman et al. 2014; Flach et al. 2014). Immunostaining to detect $\gamma-\mathrm{H} 2 \mathrm{AX}$, which reflects DNA damage foci, shows age-associated increases in DNA damage in murine and human HSCs (Rossi et al. 2007; Rübe et al. 2011). Accordingly, alkaline comet assays, to evaluate single- and double-strand breaks of genomic DNA, indicate that aged HSCs from 24- to 26-monthold mice incur elevated DNA damage when compared with cells from 3- to 4-month-old mice (Beerman et al. 2014). Compared with committed hematopoietic progenitors, these HSCs show lower expression of genes associated with DNA damage responses, including homologous recombination (HR), nonhomologous end-joining (NHEJ), and base excision repair (BER) mechanisms of DNA repair. Decreased expression of DNA repair genes is observed in quiescent HSCs from young as well as aged mice, suggesting that the defective DNA damage response correlates with stem-cell quiescence and not with an aging-related defect. Indeed, any signs of accumulated DNA damage in aged HSCs disappear by activating cell-cycle progression in these cells. This activation of cell division can be induced by culturing HSCs in a cytokine-enriched medium that promotes cell-cycle entry, in vivo injection of mice with 5fluorouracil (5-FU), which kills cycling committed progenitor cells and promotes HSC mitosis, or transplantation of aged HSCs into irradiated recipient mice (Beerman et al. 2014). 
Collectively, these results suggest that the DNA damage response and DNA repair machinery are dampened yet functional in quiescent HSCs, and that exit of HSCs from $\mathrm{G}_{0}$ phase into the cell cycle leads to induction of DNA repair even in aged HSCs. Thus, the accumulation of DNA damage in HSCs is most likely due to their quiescence rather than aging.

The accumulating $\gamma-\mathrm{H} 2 \mathrm{AX}$ foci in aged HSCs can be separated into replication-associated $\gamma$-H2AX foci, resulting from canonical DNA damage repair, and nucleolar-associated $\gamma$-H2AX foci, resulting from noncanonical ribosomal biogenesis (Flach et al. 2014). The accumulation of replication-associated $\gamma$-H2AX foci in cycling aged mouse HSCs may therefore be due to decreased expression of minichromosome maintenance (MCM) helicase components, whereas residual replication stress on ribosomal DNA (rDNA) genes may induce nucleolar-associated $\gamma$-H2AX foci, caused by a failure of $\mathrm{H} 2 \mathrm{AX}$ dephosphorylation, in quiescent aged HSCs. This failure is due to the mislocalization of the PP4c protein phosphatase in the cytoplasm of quiescent aged HSCs, whereas PP4c localizes at the nucleoli in quiescent and cycling young HSCs (Flach et al. 2014). The presence of nucleolar-associated $\gamma$-H2AX foci leads to silencing of rDNA genes and eliminates ribosomal biogenesis in quiescent aged HSCs (Flach et al. 2014). These findings may implicate a decrease in ribosomal biogenesis in the BM failure of aged HSCs.

The capacity for lineage-biased commitment of HSCs is also altered with aging. HSCs in a young animal possess a balanced capacity to generate lymphoid and myeloid progenitor cells, whereas HSCs in an aged animal tend to propagate more My-HSCs than Ly-HSCs (Cho et al. 2008; Challen et al. 2010; Benz et al. 2012; Verovskaya et al. 2013). Indeed, aged lower side population LSK cells generate relatively more myeloid cells than aged upper side population HSCs (i.e., $32.9 \%$ vs. $2.6 \%$, at 16 weeks after transplantation into mice) (Challen et al. 2010). In contrast, upper side population HSCs maintain their capacity to produce B and $\mathrm{T}$ cells for 4 and 16 weeks, respectively, posttransplantation. The lower side population of HSCs, which is enriched for My-HSCs, accumulates in the BM of aged mice, whereas the upper side population, enriched for Ly-HSCs, is reduced with age in mouse BM (Challen et al. 2010). The age-associated reduction in lymphoid differentiation potential may be responsible for the elevated risks of inflammatory, infectious, and/or autoimmune disorders in elderly animals and humans (Geiger et al. 2013; Blank and Karlsson 2015).

With low levels of TGF- $\beta$ stimulation predominantly promoting My-HSC self-renewal and myeloid differentiation (Challen et al. 2010), it is not fully understood how TGF- $\beta$ signaling promotes the shift in differentiation capacity of HSCs that occurs with aging. TGF$\beta$-induced transcriptional changes in aged HSCs may be attenuated by epigenetic alterations (Sun et al. 2014), which bolsters the case for a scenario in which an age-associated reduction in TGF- $\beta$ stimulation preferentially sustains a commitment to My-HSC generation.

The transcription factor named transcription intermediary factor $1 \gamma$ (TIF $1 \gamma$; also known as tripartite motif family 33, Trim33) has also been implicated in the phenotypes of physiologically aging HSCs (Quéré et al. 2014). Tiflg mRNA expression is decreased in long-term HSCs of 20-month-old mice, compared with 4-month-old mice. Consistent with this observation, young Tif $1 g^{-/-}$mice show phenotypes that normally characterize premature hematopoietic aging (Quéré et al. 2014). Like aged wild-type mice, young Tiflg ${ }^{-1-}$ mice show a decrease in lymphoid cells and an increase in myeloid cells compared with young wild-type mice. The E3 polyubiquitin ligase activity of TIF1 $\gamma$ may promote proteasomal degradation of the TßRI receptor (Quéré et al. 2014). Thus, HSCs isolated from $\mathrm{Tiflg}^{-/-}$mice show a marked increase in T $\beta R I$ levels compared with wild-type HSCs, indicating that TIF $1 \gamma$ normally suppresses TGF- $\beta$ signaling in vivo. The decrease in Tiflg mRNA in HSCs from aged mice correlates with a higher sensitivity to TGF- $\beta$ stimulation when compared with HSCs from young mice (Quéré et al. 2014). Furthermore, comparing murine long-term HSCs (i.e., $\mathrm{CD} 150^{+} \mathrm{CD} 48^{-}$LSK cells), with high versus 
low T $\beta R I$ expression cells reveals an inverse correlation between TIF1 $\gamma$ and T $\beta$ RI expression. Transplantation experiments showed that the higher T $\beta R I$-expressing long-term HSCs mainly support myeloid-biased differentiation, whereas lower T $\beta R I$-expressing long-term HSCs show both myeloid and lymphoid lineage commitment. These findings suggest that the decrease in TIF1 $\gamma$ in aged HSCs enhances the sensitivity to TGF- $\beta$ by increasing the abundance of T $\beta$ RI protein, and that TGF- $\beta$ signaling supports the commitment to My-HSCs during aging. Future studies are needed to define the molecular basis underlying the role of TGF- $\beta$ signaling in HSC fate determination during aging.

\section{TGF- $\beta$ Signaling in the HSC Niche}

TGF- $\beta$ is a critical factor in the HSC BM niche, necessary for both maintaining the self-renewal capacity of the HSCs and determining their cell fate (Suda et al. 2005; Lo Celso and Scadden 2011; Wang and Wagers 2011; Morrison and Scadden 2014). TGF- $\beta$ proteins are produced in a latent form and must be processed to be activated (Horiguchi et al. 2012; Robertson and Rifkin 2016). Although HSCs can produce latent TGF- $\beta$, these cells themselves may not be able to process it (Yamazaki et al. 2009) and appear to depend on other cell types for production of active TGF- $\beta$ (Yamazaki et al. 2011). The HSC niche in the BM comprises nonmyelinating Schwann cells that ensheath sympathetic nerves. These glial fibrillary acidic protein (GFAP)-expressing cells express integrin $\beta 8$ at the cell surface, which mediates activation of latent TGF- $\beta$, resulting in conversion of latent TGF- $\beta 1$ into its active form (Fig. 3) (Yamazaki et al. 2011). Consequently, HSCs that are localized in close proximity to glial cells show Smad2 and Smad3 activation, resulting from activation of TGF- $\beta$ signaling. Selective sympathetic denervation in mice substantially decreases the levels of Smad2 and Smad3 activation, leading to reduced numbers of glial cells and HSCs in BM. Cell-cycle analysis after denervation revealed that administration of active but not latent TGF- $\beta$ suppresses the active cycling of
HSCs in denervated mice. These results show that glial cells are bona fide niche components that play an important role in regulating HSC quiescence through the cytostatic effect of active TGF- $\beta$ (Yamazaki et al. 2011).

Also megakaryocytes are in physical proximity with HSCs in BM in vivo (Bruns et al. 2014; Zhao et al. 2014). To study the role of megakaryocytes in the control of HSC activity in vivo, transgenic mice harboring an inducible gene cassette to express the diphtheria toxin receptor (iDTR mice) were used, thus rendering megakaryocytes sensitive to diphtheria toxin. When megakaryocytes are depleted by in vivo administration of diphtheria toxin, long-term HSCs undergo cell division and increase their numbers (Bruns et al. 2014). Megakaryocytes express the $\mathrm{C}-\mathrm{X}-\mathrm{C}$ motif ligand 4 (CXCL4, also known as platelet factor 4) chemokine. Injection of CXCL4 into mice decreases the HSC numbers by promoting stem-cell quiescence. Conversely, untreated $\mathrm{Cxcl} 4^{-/-}$mice show an increase in HSCs compared with untreated wild-type mice (Bruns et al. 2014). These results show that megakaryocytes regulate HSC "stemness" in vivo and raise the possibility that CXCL4 contributes to HSC quiescence (Bruns et al. 2014).

Additionally, megakaryocytes express high levels of Tgfbl mRNA (Zhao et al. 2014), and HSCs positioned in close proximity to megakaryocytes show activation of Smad2 and Smad3, consistent with activation of TGF- $\beta$ signaling. Diphtheria toxin-induced megakaryocyte ablation decreases the level of active TGF$\beta 1$ in the BM of these mice, as well as the levels of activated Smad2 and Smad3 in their longterm HSCs, and increases the size of the longterm HSC population while decreasing the number of $G_{0}$ phase quiescent long-term HSCs (Zhao et al. 2014). TGF- $\beta 1$ administration to megakaryocyte-depleted mice restores HSC quiescence (Zhao et al. 2014). In contrast, conditional disruption of the $\mathrm{Tg} f b 1$ gene in megakaryocytes abrogates HSC quiescence. Thus, megakaryocytes are a major source of TGF- $\beta$, which is needed to promote the selfrenewal capacity in HSCs (Zhao et al. 2014). These results highlight the roles of various cell 
K. Naka and A. Hirao

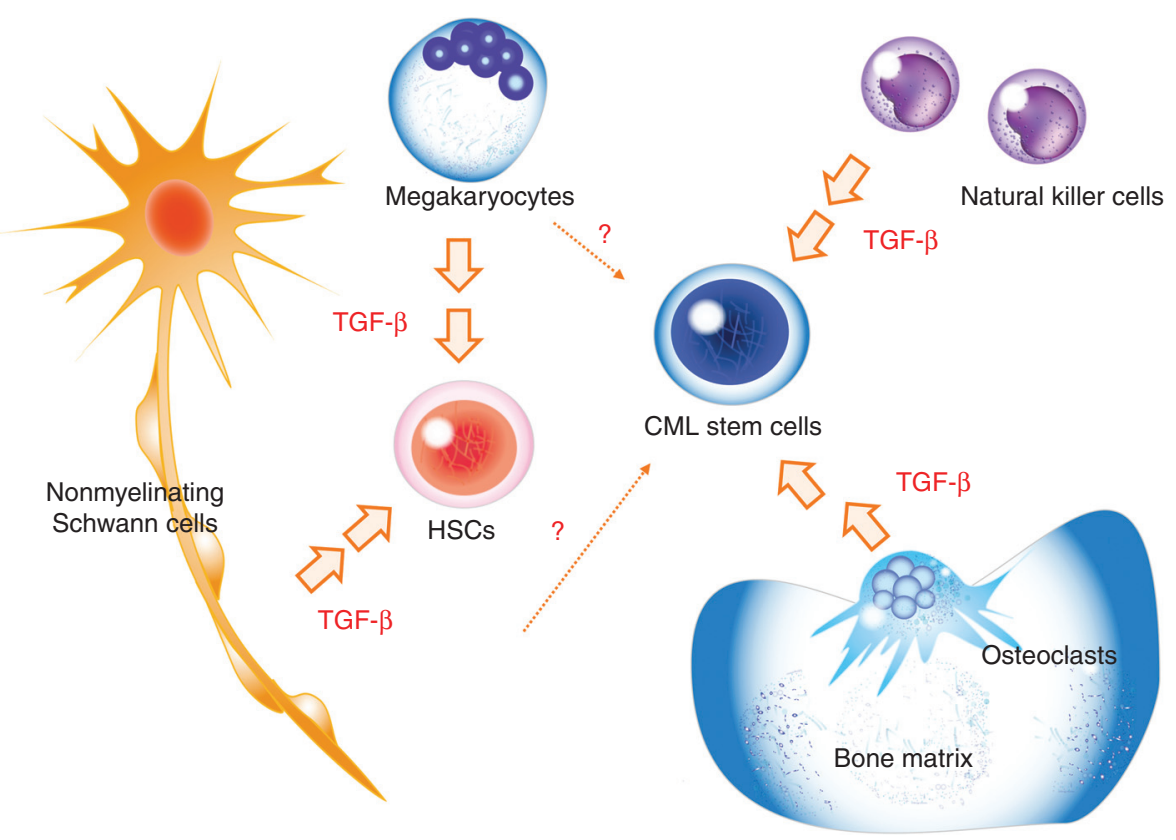

Figure 3. Sources of transforming growth factor $\beta$ (TGF- $\beta$ ) in the hematopoietic stem cell (HSC) and chronic myelogenous leukemia (CML) stem-cell niche in mice. Within the BM microenvironmental niche in mice, TGF$\beta$ is a key factor regulating the self-renewal capacity of both HSCs and CML stem cells. TGF- $\beta$ produced in its latent form by HSCs is processed into its active form by adjacent nonmyelinating Schwann cells. Megakaryocytes are a source of TGF- $\beta$ to maintain HSCs. This TGF- $\beta$ may also support the self-renewal and quiescence of CML stem cells. Natural killer (NK) cells are a possible source of TGF- $\beta$ driving the resistance of CML stem cells to tyrosine kinase inhibitors. Osteoclasts that resorb bone matrix and thus release stored TGF- $\beta$ during bone regeneration may also contribute to self-renewal of CML stem cells.

types in defining the TGF- $\beta$ signaling in the BM niche, and their regulatory effects on HSC properties in vivo.

Endoglin (CD105), a transmembrane glycoprotein, functions as an ancillary nonsignaling TGF- $\beta$ receptor (Barbara et al. 1999). Mutations in the Eng gene were discovered in patients with hereditary hemorrhagic telangiectasia type 1 (HHT1), a disease characterized by excessive bleeding due to vascular malformations (McAllister et al. 1994). Endoglin is highly expressed in long-term repopulating HSCs (Chen et al. 2002). Similar to the phenotypes of $\mathrm{Tgfb}^{-1-}$ or $\mathrm{Tgfbr} 2^{-/-}$mice, Eng ${ }^{-/-}$ mouse embryos fail to form mature blood vessels in the yolk sac, suggesting a role for endoglin in TGF- $\beta 1$ signaling in vivo (Arthur et al. 2000). In transplantation experiments, endoglin-positive and endoglin-negative side population cells show a comparable BM reconstitution capacity at 4 weeks posttransplantation. However, whereas the BM reconstitution capacity of endoglin-negative cells decreases after 4 weeks, mice that receive the endoglin-positive cells maintain a high level of HSC self-renewal for 14 and 26 weeks. Thus, by supporting TGF- $\beta$ signal transduction in the in vivo microenvironment, endoglin plays an important role in maintaining the self-renewal capacity of longterm repopulating HSCs.

\section{TGF- $\beta$ Signaling in HSC Quiescence}

Multiple lines of evidence indicate that stemcell quiescence is essential to maintain the long-term self-renewal capacity of HSCs in vivo (Eliasson and Jonsson 2010). Several proteins are required to establish HSC quiescence. 
Among these, the CDK inhibitor $\mathrm{p} 21^{\text {Waf1/Cip } 1}$ is essential to retain HSCs in the $\mathrm{G}_{0} / \mathrm{G}_{1}$ phase so that they maintain their self-renewal capacity (Cheng et al. 2000). Analysis of quiescent cells stained with the RNA dye pyronin Y (PY) revealed that, compared with wild-type mice, the absence of $\mathrm{p} 21^{\text {Waf1/Cip } 1}$ in $C d k n 1 a^{-/-}$mice results in a decreased proportion of immature lineage-negative cells in the $\mathrm{G}_{0}$ phase cells. Furthermore, Cdkn1a $a^{-/-}$HSCs exhaust their selfrenewal capacity more rapidly than wild-type HSCs, as shown by serial transplantation. Another CDK inhibitor, p57 $7^{\mathrm{Kip} 2}$, which is highly expressed in human hematopoietic stem/progenitor cells (HSPCs) (Scandura et al. 2004) and primitive murine long-term HSCs (Yamazaki et al. 2006; Matsumoto et al. 2011; Zou et al. 2011), has also been shown to control HSC quiescence. HSCs isolated from mice deficient for the $C d k n 1 c$ gene encoding p57 ${ }^{\mathrm{Kip} 2}$ show a decreased proportion of the HSC population in the $\mathrm{G}_{0}$ phase (Matsumoto et al. 2011; Zou et al. 2011). BM reconstitution analyses revealed that $C d k n 1 c$-deficient HSCs have a decreased capacity for self-renewal in transplanted mice compared with wild-type HSCs (Matsumoto et al. 2011; Zou et al. 2011). Thus, both CDK inhibitors $\mathrm{p} 21^{\text {Waf1/Cip } 1}$ and $\mathrm{p} 57^{\mathrm{Kip} 2}$ regulate stem-cell quiescence and HSC self-renewal capacity.

Forkhead O (FOXO) transcription factors, which include FOXO1, FOXO3a, FOXO4, and FOXO6, are also critical for controlling HSC functions (Miyamoto et al. 2007; Tothova et al. 2007; Yalcin et al. 2008; Warr et al. 2013). FOXO transcription factors regulate the detoxification of reactive oxygen species (ROS) and autophagy in HSCs (Miyamoto et al. 2007; Tothova et al. 2007; Yalcin et al. 2008; Warr et al. 2013). They also help to prevent HSC aging in vivo; accordingly, the size of the HSC fraction is decreased in 80-week-old Foxo3a-deficient mice compared with wild-type littermate controls (Miyamoto et al. 2007). Additionally, FOXO transcription factors contribute to the maintenance of HSC quiescence. Mice with a triple conditional disruption of the Foxo1, Foxo3a, and Foxo 4 genes show a significant decrease in BM long-term HSCs (Tothova et al. 2007). BM reconstitution analyses of HSCs from these mutants show that loss of all three genes, or loss of Foxo3a alone, reduces the self-renewal capacity of HSCs in vivo. These mutant HSCs also show decreased expression of $\mathrm{p} 27^{\mathrm{Kip} 1}$ and $\mathrm{p} 57^{\mathrm{Kip} 2}$, leading to defective HSC quiescence. Importantly, the $C d k n 1 c$ gene, encoding $\mathrm{p} 57^{\mathrm{Kip} 2}$, is a FOXO3a target gene, suggesting that a $\mathrm{FOXO}-\mathrm{p} 57^{\mathrm{Kip} 2}$ axis may play a key role in controlling HSC quiescence in vivo (Miyamoto et al. 2007; Tothova et al. 2007; Yalcin et al. 2008). This axis may be linked to TGF- $\beta$ signaling through Smad3, because Smad3 binds directly to FOXO factors to enhance their transcriptional activity (Seoane et al. 2004). These results suggest that TGF- $\beta-$ Smad3 signaling can connect $\mathrm{FOXO}-\mathrm{p} 57^{\mathrm{Kip} 2}$ signaling to regulate HSC quiescence and selfrenewal (Fig. 4). Indeed, treatment of human HSPCs and murine long-term HSCs with TGF- $\beta 1$ in cell culture induces p $57^{\mathrm{Kip} 2}$ expression (Scandura et al. 2004; Yamazaki et al. 2009). Thus, a TGF- $\beta-\mathrm{FOXO}-\mathrm{p} 57^{\mathrm{Kip} 2}$ axis appears to be crucial for HSC quiescence and maintenance of self-renewal capacity.

Promyelocytic leukemia (PML) tumor suppressor protein is also important for quiescence and, thus, the long-term repopulation capacity of HSCs in vivo (Ito et al. 2008). The PML protein participates in diverse cellular activities, including the DNA damage response, apoptosis, cellular senescence, tumor suppression, and stemness. Pml mRNA levels are higher in normal long-term HSCs than in progenitors or mature hematopoietic cells (Ito et al. 2008). Competitive repopulation assays in transplanted mice have indicated that $P m l^{-/-}$HSCs have a lower BM reconstitution capacity than $\mathrm{Pml}^{+/+}$ HSCs, and that $\mathrm{Pml}^{-/-}$long-term HSCs (CD34 ${ }^{-}$LSK cells) show a lower proportion of $\mathrm{G}_{0}$ phase cells, when compared with $\mathrm{Pml}^{+/+}$ CD34 ${ }^{-}$LSK cells. This may relate to the role of PML in controlling peroxisome proliferator-activated receptor- $\delta$ (PPAR- $\delta$ ) activity and the fatty acid oxidation (FAO) levels, which are crucial to the maintenance and asymmetric cell division of HSCs (Ito et al. 2012). Ligand-activated PPAR- $\delta$ was reported to induce the expression of TGF- $\beta$ in human dermal fibroblasts (Ham et al. 2010, 2015), but it remains to be seen 


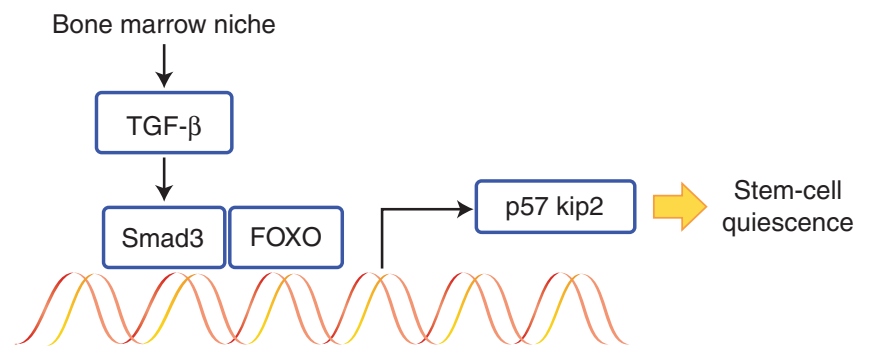

Figure 4. Transforming growth factor $\beta$ (TGF- $\beta$ ) and Forkhead O (FOXO) signaling cooperate to ensure hematopoietic stem cell (HSC) quiescence. The activities of FOXO transcription factors lead to expression of the $C d k n 1 c$ gene encoding the CDK inhibitor $\mathrm{p} 57^{\mathrm{Kip} 2}$, which is essential for sustaining HSC quiescence. TGF- $\beta$ signaling in the bone marrow (BM) niche induces $\mathrm{p} 57^{\mathrm{Kip} 2}$ expression in HSCs. Because TGF- $\beta$ signaling activates Smad3, and Smad3 can associate with FOXO transcription factors to induce $\mathrm{p} 57^{\mathrm{Kip} 2}$ production, a functional axis that integrates TGF- $\beta$ signaling through Smad 3 and FOXO proteins may control HSC quiescence and maintenance.

whether a functional link between PPAR- $\delta$ and TGF- $\beta$ signaling cooperates in the asymmetric division of HSCs, and contributes to the maintenance of HSC self-renewal capacity in vivo.

The E3 ubiquitin ligase Fbwx7 (F-box and WD-40 domain protein 7; also called Fbw7) is also involved in the maintenance of HSC quiescence and self-renewal (Matsuoka et al. 2008; Thompson et al. 2008; Reavie et al. 2010). Conditional $\mathrm{Fb} \times w 7^{-/-}$mice show defective longterm HSC maintenance (Matsuoka et al. 2008; Thompson et al. 2008), and $F b x w 7^{-/-}$HSCs have less self-renewal capacity in transplanted mice than control HSCs (Matsuoka et al. 2008; Thompson et al. 2008). In HSCs, disruption of the $F b w x 7$ gene induces stabilization of the c-Myc oncoprotein and suppression of expression levels of the p53 tumor suppressor protein, causing a failure in stem-cell quiescence (Matsuoka et al. 2008; Thompson et al. 2008; Reavie et al. 2010). Whereas enforced overexpression of c-Myc induces HSC differentiation, long-term HSCs in $\mathrm{Myc}^{-/-}$mice undergo excessive self-renewal, indicating a crucial role of $\mathrm{c}-\mathrm{Myc}$ in HSC maintenance (Wilson et al. 2004). In response to TGF- $\beta$, activated Smad 3 cooperates with c-Myc to suppress the expression of the $C d k n 2 b$ gene encoding $\mathrm{p} 15^{\text {Ink } 4 \mathrm{~B}}$ protein (Feng et al. 2002), raising the possibility that this cooperation in the expression of $\mathrm{p} 15^{\text {Ink }} 4 \mathrm{~B}$ or other gene products may contribute to HSC maintenance and quiescence. A possible role of Fbxw7 in HSC maintenance is supported by the observation that loss of the $F b x w 7$ gene in $\mathrm{T}$ cells leads to the development of T-cell acute lymphoblastic leukemia (T-ALL) (Matsuoka et al. 2008). Thus, Fbxw7 regulates HSC quiescence and self-renewal capacity in vivo as well as resistance to tumorigenesis in $\mathrm{T}$ cells.

Collectively, these mouse genetic studies reinforce the notion that stem-cell quiescence is crucial for the long-term maintenance of HSCs in vivo.

Possible Cross Talk between TGF- $\beta$ and Stemness Signaling in HSC Homeostasis

Wnt $-\beta$-catenin signaling, which is required for the maintenance of several types of adult tissue stem cells (Reya et al. 2001; Reya and Clevers 2005), is also important in the control of HSC homeostasis (Reya et al. 2003; Scheller et al. 2006; Zhao et al. 2007). Ectopic expression of axin or a frizzled ligand-binding domain, which inhibit Wnt signaling, suppresses HSC proliferation in vitro and reduces the $\mathrm{BM}$ reconstitution capacity of HSCs in vivo (Reya et al. 2003). In contrast, enforced expression of activated $\beta$-catenin increases HSC proliferation in vitro (Reya et al. 2003). Mice with a conditionally disrupted $C t n n b 1$ gene encoding $\beta$-catenin produce HSCs that cannot maintain their long-term self-renewal ability. These findings imply that regulation of the Wnt $-\beta$-catenin signaling pathway is 
required to support normal HSC stemness. Because $\beta$-catenin and Smad3 cooperate to control transcriptional activity in response to TGF$\beta$ (Zhou et al. 2012), Wnt- $\beta$-catenin signaling may cross talk or cooperate TGF- $\beta-$ Smad 3 in the control of HSC stemness.

The tumor suppressor kinase LKB1, which regulates AMPK activity in response to low levels of intracellular energy (i.e., the ATP/AMP ratio), has key functions in cell proliferation, energy metabolism, and mitochondrial biogenesis (Shackelford and Shaw 2009). Loss of the Lkb1 gene leads to a decrease in HSC quiescence, indicating an essential role for LKB1 in HSC quiescence and self-renewal capacity (Gan et al. 2010; Gurumurthy et al. 2010; Nakada et al. 2010). LKB1 was shown to interact with Smad4 through the scaffolding protein LKB1interacting protein 1 (LIP1), and represses the TGF- $\beta$-induced transcriptional activation of a reporter system containing tandem Smad3Smad4 binding sites (Morén et al. 2011). Thus, cross talk between TGF- $\beta$ and LKB1 signaling may help control HSC homeostasis in a context-dependent manner (i.e., under low energy and/or nutrient conditions within the HSC niche). Thus, TGF- $\beta$-Smad signaling controls several molecular mechanisms that are important for HSC stemness in vivo.

\section{TGF- $\beta$ SIGNALING IN HEMATOLOGICAL DISEASE}

The World Health Organization (WHO) system for classifying hematological disorders takes into account a patient's clinical features and the morphology of the abnormal cells, as well as diseaseassociated genetic and/or chromosomal changes that have been well defined using next-generation sequencing (Swerdlow et al. 2008; Arber et al. 2016). The acquisition of DNA alterations by hematopoietic cells affects their proliferative capacity and can drive the development of hematological disease. Several lines of evidence indicate that genetic and/or epigenetic changes that alter TGF- $\beta$ signaling are relevant in this context, and that TGF- $\beta$ signaling acts as a double-edged sword whose activation or suppression can lead to dysregulation and imbalance in sig- naling pathways and cell populations required for normal hematopoiesis. Hematological diseases and/or malignancies can then result.

\section{TGF- $\beta$ Signaling in Fanconi Anemia}

Fanconi anemia (FA) is an autosomal recessive disorder characterized by anemia, progressive BM failure, and a high risk of developing a hematological malignancy, such as MDS or acute myelogenous leukemia (AML) (Fanconi 1967). FA is caused by mutation of any one of the 18 FANC genes (FANC-A, B, C, D1, D2, E, F, G, I, $J, L, M, N, O, P, Q, S$, and $T)$. The products of these genes normally cooperate with BRCA1 and BRCA2 tumor suppressors and DNA damage checkpoint proteins to repair DNA interstrand cross-links (ICLs), although the molecular mechanism is not well defined (Kim and D’Andrea 2012; Kottemann and Smogorzewska 2013; Sawyer et al. 2015). Disruption of the FA pathway results in highly active TGF- $\beta$ signaling in HSCs, which results in BM failure characteristic of FA (Zhang et al. 2016).

Dividing cells in the $S$ phase of the cell cycle carry out accurate DNA repair using the HRmediated mechanism and the sister chromatid as template. In contrast, quiescent HSCs repair damaged DNA using the error-prone NHEJ process, so that HSCs tend to be susceptible to DNA damage (Mohrin et al. 2010). Using the traffic light reporter (TLR) system, which quantifies both HR and NHEJ activities (Certo et al. 2011), human FA-A fibroblasts were shown to prefer NHEJ over the HR repair pathway. Treatment of FA cells in vitro with the TRRI kinase inhibitor SD208, or with lentiviral transduction of short-hairpin RNA (shRNA) to silence Smad3 expression, promotes HR and attenuates NHEJ activities (Zhang et al. 2016). Thus, induction of strong TGF- $\beta$ signaling in FA cells might promote cell-cycle arrest and increase susceptibility to DNA damage due to NHEJ repair before $\mathrm{BM}$ failure.

Inhibition of TGF- $\beta$ signaling using antiTGF- $\beta$ neutralizing antibody promotes DNA repair and improves the BM reconstitution capacity of HSCs isolated from Fancd $2^{-/}$mice (Zhang et al. 2016). Consistent with this obser- 
vation, treatment of $\mathrm{CD} 34^{+}$cells from FA patients with the anti-TGF- $\beta$ neutralizing antibody GC1008 increases their in vitro colony forming capacity (Zhang et al. 2016). These results suggest that excessive activation of TGF- $\beta$ signaling causes the BM failure of FA, and that inhibition of TGF- $\beta$ signaling might restore HSC and BM functionality in FA patients.

\section{Roles of TGF- $\beta$ Signaling in CML \\ TGF- $\beta$ Signaling in CML Stem Cells}

TGF- $\beta$ signaling supports the self-renewal capacity and therapeutic resistance of cancer stem cells, which give rise to the vast majority of mature cancer cells in solid tumors (Ikushima et al. 2009; Peñuelas et al. 2009; Oshimori et al. 2015). In patients with CML recurrence, the reappearance of leukemia is due to the generation of large numbers of mature CML cells from a rare population of therapy-resistant CML stem cells. Whereas suppression of TGF- $\beta$ signaling can trigger leukemogenesis, TGF- $\beta$ signaling paradoxically preserves the self-renewal capacity of the CML stem cells driving CML disease.

Several lines of evidence implicate normal HSCs as the cells-of-origin of CML stem cells expressing the $B C R-A B L 1$ oncogene (O'Hare et al. 2012; Naka and Hirao 2013). Tyrosine kinase inhibitors such as imatinib mesylate, dasatinib, nilotinib, and bosutinib that inhibit the BCR-ABL1 oncoprotein dramatically suppress mature CML cells and improve the prognosis of CML patients; however, they are unable to completely eliminate quiescent CML stem cells (O'Hare et al. 2012). Thus, tyrosine kinase inhibitors may need to be combined with novel therapeutics capable of eradicating quiescent CML stem cells to prevent disease recurrence in CML patients.

Because CML stem cells originate from normal HSCs, it has been of great interest to examine whether CML stem cells conserve the regulatory mechanisms found in normal HSCs. Because TGF- $\beta$ signaling regulates the functions of FOXO transcription factors in normal HSCs (Yamazaki et al. 2009), and FOXO proteins control the self-renewal capacity of HSCs
(Miyamoto et al. 2007; Tothova et al. 2007; Yalcin et al. 2008; Warr et al. 2013) and the longterm maintenance of CML stem cells (Naka et al. 2010; Pellicano et al. 2014), the therapeutic impact of TßRI kinase inhibitors on CML stem-cell survival in vivo has been investigated (Naka et al. 2010, 2016). Treatment with either LY364947 or EW-7197 alone does not extend the survival of CML-affected mice, but combined administration of either T $\beta$ RI kinase inhibitor with tyrosine kinase inhibitors greatly reduces the recurrence of CML and number of tyrosine kinase inhibitor-resistant CML stem cells in vivo. Furthermore, TGF- $\beta$ inhibitors impair the viability of human $\mathrm{CD} 34^{+} \mathrm{CD} 38^{-}$ CML stem/progenitor cells in culture (Møller et al. 2007; Naka et al. 2010, 2016). Thus, the intrinsic TGF- $\beta$ signaling to FOXO plays a key role in the maintenance of tyrosine kinase inhibitor-resistant CML stem cells, and may therefore represent an attractive new therapeutic target in the treatment of CML.

\section{Source of TGF- $\beta$ Sustaining CML Stem Cells}

Understanding the origin of the TGF- $\beta$ that sustains CML stem cells in vivo could lead to a novel avenue to eliminate these malignant cells. Because nonmyelinating Schwann cells in the BM activate latent TGF- $\beta$ that acts on normal HSCs (Yamazaki et al. 2011), they may also activate TGF- $\beta$ for CML stem cells (Fig. 3). Because a large amount of TGF- $\beta$ is retained in the bone matrix, resorption of bone matrix by osteoclasts during bone regeneration may represent another source of TGF- $\beta$ for CML stem cells. Accordingly, osteoclasts were shown to maintain CML cells dormant through the release of TGF- $\beta$ via bone resorption (Yokota et al. 2010). In addition, a study of 174 CML patients on imatinib therapy found that expression of KIR2DS1, which encodes a "killer cell immunoglobulin-like receptor," in a subset of natural killer (NK) cells correlates with shorter progression-free survival and reduced overall survival (Marin et al. 2012). NK cells expressing KIR2DS1 secrete TGF- $\beta$, suggesting that they may act as a source of TGF- $\beta$ that drives the 
resistance of CML stem cells to tyrosine kinase inhibition (Ghio et al. 2009). On the other hand, high levels of TGF- $\beta 1$ released into the BM microenvironment may suppress CML stem cell activity in vivo (Krause et al. 2013). Enforced expression of the parathyroid hormone $(\mathrm{PTH})$ receptor in osteoblasts promotes bone remodeling that is associated with increased TGF- $\beta$ expression. Not coincidentally, CML-affected mice overexpressing TGF- $\beta 1$ in the BM niche show prolonged overall survival (Krause et al. 2013), which is most likely due to PTH-mediated activation of TGF- $\beta 1$ that induces deep quiescence of CML stem cells.

\section{An "Integrator" Role for Smad3 in CML Stemness}

Smad3 is the master regulator of TGF- $\beta$ signaling involved in determining cell fate, stem- ness, EMT, and metastasis (Massagué 2012). As noted already, Smad3 is phosphorylated at the two carboxy-terminal serines by the activated T $\beta$ RI kinase (Hata and Chen 2016), and Smad3 linker region phosphorylation helps maintain CML stem cells in vivo (Naka et al. 2015). In mice, normal HSCs and CML stem cells show metabolic differences whereby CML stem cells, but not normal HSCs, take up dipeptide species as an alternative nutrient to maintain CML stem cell survival in vivo (Fig. 5). These internalized dipeptide species promote signaling that results in p38 MAPK activation and Smad3 linker phosphorylation at Ser208 by p38 MAPK to support CML stem cell self-renewal in vivo (Naka et al. 2015). Thus, Smad3 integrates canonical TGF- $\beta$ signaling and noncanonical nutrient signaling in CML stem cells to maintain their capacity for self-renewal.

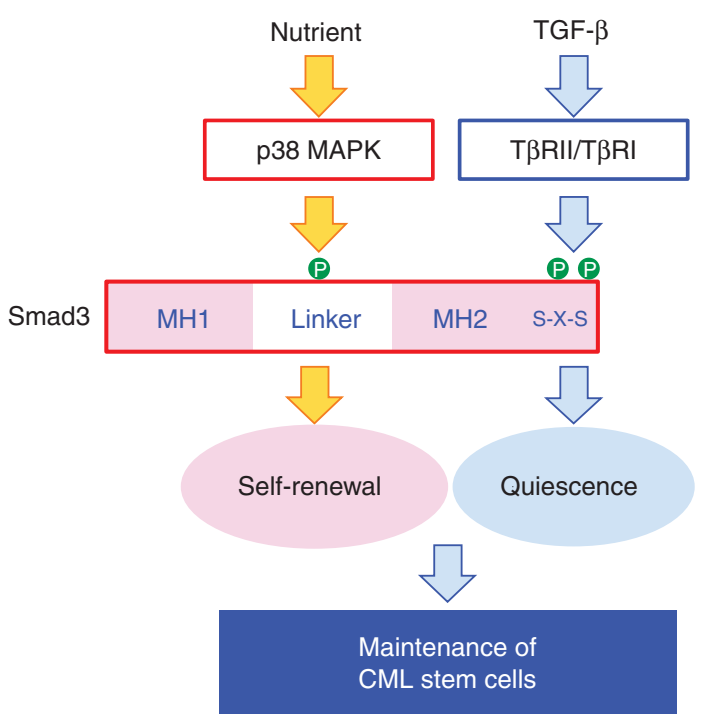

Figure 5. An "integrator" role for Smad3 in the maintenance of chronic myelogenous leukemia (CML) stemness. Smad3 participates in nutrient-activated p38 mitogen-activated protein kinase (MAPK) signaling that supports CML stem cell self-renewal and in TGF- $\beta$ signaling that supports CML stem cell quiescence. The nutrientactivated p38 MAPK pathway phosphorylates Ser208 in the Smad3 linker region. Activated T $\beta$ RI kinase phosphorylates Smad3 at the carboxy-terminal two-serine residues, which then controls stem-cell quiescence. CML stem cells show Smad3 phosphorylation at Ser208 in the linker region and at the carboxy-terminal serines. Posttranslational modification of Smad3 therefore integrates two intracellular pathways to regulate the selfrenewal capacity and resistance of CML stem cells to tyrosine kinase inhibitors. Because nutrient-activated p38 MAPK-Smad3 signaling does not occur in normal hematopoietic stem cells (HSCs), inhibitors targeting this nutrient pathway might provide clinical benefits for CML patients. 
Possible Cross Talk between JAK-STAT and TGF- $\beta-$ Smad Pathways in Myeloproliferative Neoplasms

Polycythemia vera (PV), essential thrombocythemia (ET), and primary myelofibrosis (PMF) are clonal, stem-cell-derived myeloproliferative neoplasms (MPNs). Patients with these disorders are at risk of developing BM failure and AML (Swerdlow et al. 2008; Arber et al. 2016). Genetic changes in these MPNs typically affect the functions of Janus kinase 2 (JAK2), calreticulin (CALR), or the myeloproliferative leukemia virus oncogene $(M P L)$ proteins (Vainchenker and Constantinescu 2013; Tefferi and Pardanani 2015). Mutations of JAK2, resulting in a V617F substitution, MPL, resulting in W515K/L or S505N substitution, or $C A L R$, all generate proteins that can constitutively activate the JAK-STAT pathway independently of cytokine signaling, resulting in MPN development. For example, mouse genetic studies show that the JAK2 V617F substitution induces MPN (Shide et al. 2008; Tiedt et al. 2008; Xing et al. 2008; Akada et al. 2010; Li et al. 2010; Marty et al. 2010; Mullally et al. 2010), and interaction of a mutant CALR protein with the thrombopoietin (TPO) receptor forces the activation of the downstream JAK-STAT pathway (Araki et al. 2016). The precise molecular mechanism by which JAK-STAT activation promotes cell proliferation is unknown, but comparison of JAK1-deficient U4A cells and those following introduction of JAK1 provides evidence of cross talk between JAK-STAT and TGF- $\beta$-Smad signaling (Ulloa et al. 1999). Interferon (IFN)- $\gamma$ activates JAK1-STAT1 signaling, which inhibits TGF- $\beta$-induced activation of $S \operatorname{mad} 3$ by inducing the expression of Smad7. Smad7, in turn, interferes with the interaction of Smad2 and Smad3 with the T $\beta$ RII-T $\beta$ RI complexes, resulting in inhibition of TGF- $\beta$-induced Smad signaling (Ulloa et al. 1999). Constitutive STAT3 activation in vivo leads to similar results (Jenkins et al. 2005a). In response to interleukin (IL)-6, the receptor subunit gp130 transduces STAT3 phosphorylation that leads to activation of the Smad7 and Socs3 genes. Notably, SOCS3 suppresses gp130 activity, indicating that
SOCS3 acts in a negative feedback loop controlling gp130-STAT3 signaling. However, in mutant mice expressing gp $130^{\mathrm{Y} 757 \mathrm{~F} / \mathrm{Y} 757 \mathrm{~F}}$, SOCS3 does not suppress gp130, resulting in constitutive STAT3 activation, and induces high-level expression of Smad7 and impaired sensitivity of gp 130 ${ }^{\mathrm{Y} 757 \mathrm{~F} / \mathrm{Y} 757 \mathrm{~F}}$ cells to the cytostatic effects of TGF- $\beta$ signaling (Jenkins et al. 2005a). These mutant mice with STAT3 hyperactivation are susceptible to the development of gastric adenomas (Jenkins et al. 2005a) and hematological abnormalities, including expansion of hematopoietic progenitors, splenomegaly, and thrombocytosis (Jenkins et al. 2005b).

In contrast, in a mouse model of PMF, TGF$\beta 1$ secreted by hematopoietic cells plays an important part in the development of myelofibrosis in vivo (Chagraoui et al. 2002). HSCs isolated from $\mathrm{Tgfb} 1^{+/+}$and $\mathrm{Tgfb} 1^{-/-}$mice were induced to express TPO through retroviral Tpo transduction, and then transplanted into recipient mice. Although myelofibrosis develops in mice that received $\mathrm{Tgfb} 1^{+/+}$HSCs expressing Tpo, no such fibrosis in BM or spleen was detected in mice with $T g f b 1^{-/-}$HSCs expressing Tpo, indicating a key role for TGF- $\beta 1$ in PMF development.

Taken together, these results indicate that TGF- $\beta$ signaling has supportive as well as suppressive functions in MPN pathophysiology, depending on cellular context.

\section{TGF- $\beta$ Signaling in Myelodysplastic} Syndromes

MDS are clonal stem-cell disorders characterized by ineffective generation of mature blood cells. A key cause of MDS development is the cytostatic effect of TGF- $\beta$ signaling on HSCs and hematopoietic progenitors (Bachegowda et al. 2013). Primitive CD $34^{+}$cells from MDS patients show constitutively phosphorylated Smad2, suggesting activation of TGF- $\beta$-mediated signal transduction (Zhou et al. 2008). Furthermore, CD34 ${ }^{+}$cells from MDS patients show a decrease in expression of the inhibitory Smad7 (Zhou et al. 2008, 2011). BM samples from MDS patients show elevated levels of miR21, which suppresses Smad7 expression by 
binding directly to the $3^{\prime} \mathrm{UTR}$ of the SMAD7 mRNA (Bhagat et al. 2013). Thus, excessive TGF- $\beta$ signaling in HSPCs may attenuate the normal production of mature blood cells, leading to MDS development.

Transgenic mice, which express TGF- $\beta 1$ under the control of $A l b$ regulatory elements, constitutively secrete TGF- $\beta 1$ and serve as a mouse model of MDS (Zhou et al. 2008). In these mice, the T $\beta$ RI kinase inhibitor SD208 reduces the MDS-associated anemia (Zhou et al. 2008). Similar results were obtained using a locked nucleic acid (LNA)-modified miR-21 inhibitor (Bhagat et al. 2013). These data suggest that pharmacological targeting of TGF- $\beta$ signaling may have therapeutic benefits for MDS patients.

\section{TGF- $\beta$ Signaling in Myeloid Malignancies}

Genetic changes affecting the TGF- $\beta-$ Smad pathway are well known to impair the cytostatic response in normal epithelial cells such that carcinomas may eventually develop (Wakefield and Roberts 2002; Massagué 2008). In parallel, chromosomal alterations that affect TGF- $\beta$ signaling have been implicated in myeloid hematological malignancies, such as AML and the fatal "blast crisis" phase of CML (Kim and Letterio 2003; Larsson and Karlsson 2005; Dong and Blobe 2006; Blank and Karlsson 2011; Naka and Hirao 2013). For example, the $\mathrm{t}(8 ; 21)(\mathrm{q} 21.3 ; \mathrm{q} 22.12)$ translocation, which generates the AML1-ETO fusion oncoprotein, generates AML characterized by immature myeloid cells (Swerdlow et al. 2008). The normal AML1 protein, also known as Runx1, CBFA2, or $\mathrm{PEBP} 2 \alpha \mathrm{B}$, is a member of the runt transcription factor family. The normal ETO protein, also known as MTG8, is involved in transcriptional regulation through recruitment of corepressors such as N-CoR, mSin3A, and SMRT. The acetylation of an essential lysine residue in the AML1-ETO fusion oncoprotein by the transcriptional coactivator p300 is crucial for AML initiation (Wang et al. 2011). The AML1-ETO protein inhibits Smad3's ability to bind DNA and thus suppresses TGF- $\beta$ Smad3 signaling. Therefore, TGF- $\beta$ signaling may abrogate the tumor-suppressive function of AML1-ETO and thus the initiation or progression of AML1-ETO-driven AML (Jakubowiak et al. 2000).

Acute promyelocytic leukemia (APL) is an AML subtype associated with the $t(15 ; 17)$ (q22;q21) chromosomal translocation, and is characterized by accumulation of abnormal granulated promyelocytes in the BM and peripheral blood (Swerdlow et al. 2008). This translocation produces a PML-RAR $\alpha$ fusion oncoprotein in which the PML protein is attached to the retinoic acid receptor $\alpha(\operatorname{RAR} \alpha)$. The normal PML protein has been implicated in multiple cellular functions, including DNA damage response, apoptosis, tumor suppression, and stemness. The normal RAR $\alpha$ protein regulates all-trans-retinoic acid (ATRA)-mediated transcriptional signal transduction. Treatment of APL patients with ATRA can induce PML-RAR $\alpha$ degradation and stimulate the maturation of APL cells into myeloid-like cells. A cytoplasmic isoform of PML (cPML) interacts with Smad2 and Smad3 as well as SARA (Smad anchor for receptor activation), and is required for TGF- $\beta$ signaling (Lin et al. 2004). PML-RAR $\alpha$ inhibits cPML function and blocks TGF- $\beta$ signaling, suggesting that weakening of TGF- $\beta$ 's cytostatic effects contributes to APL leukemogenesis (Lin et al. 2004).

CML is an MPN that progresses through three phases: an initial chronic phase, an accelerated phase, and the blast crisis phase noted above (Ren 2005). Most CML patients have a $\mathrm{t}(9 ; 22)$ (q34;q11.2) translocation that generates the $B C R-A B L 1$ fusion oncogene encoding a constitutively active tyrosine kinase (Rowley 1973; de Klein et al. 1982). Additional genetic and epigenetic changes then drive the progression of the disease to the accelerated phase and the fatal blast crisis. Among these genetic changes is the $\mathrm{t}(3 ; 21)(\mathrm{q} 26.2 ; \mathrm{q} 22.12)$ translocation, which generates the AML1-EVI1 fusion oncoprotein observed in blast crisis CML patients. The normal EVI1 protein encodes a zinc-finger transcription factor that is known to regulate HSC maintenance (Yuasa et al. 2005; Goyama et al. 2008). Excess expression of EVI1 alone can also cause blast crisis CML (Mitani et al. 1994; Ogawa et al. 1996; Sato et al. 
2014). Notably, both the normal EVI1 protein and the AML1-EVI1 oncoprotein inhibit Smad3 function during TGF- $\beta$ signal transduction (Kurokawa et al. 1998a,b). These findings indicate that chromosomal alterations that interfere with TGF- $\beta$ signaling can lead to myeloid malignancies.

\section{TGF- $\beta$ Signaling in Lymphoid Malignancies}

Genetic alterations that attenuate TGF- $\beta$ signaling also promote ALL, which originates from $\mathrm{T}$ or B lymphocyte lineage cells. The expression of Smad2 and Smad3 in children with T-cell ALL, pre-B-cell ALL, or acute nonlymphoblastic leukemia (ANLL) has been studied (Wolfraim et al. 2004). Although Smad2 levels are normal and similar in all ALL subtypes, Smad3 levels are lower in leukemic cells from T-cell ALL patients, but not in leukemic cells from pre-B-cell ALL or ANLL patients (Wolfraim et al. 2004). Genetic studies in mice suggest a molecular mechanism of T-cell ALL development that involves TGF- $\beta$ signaling. Although mice with loss of a single Smad3 allele show attenuation of TGF- $\beta$ 's cytostatic effects on normal $\mathrm{T}$ cells, heterozygous deletion of Smad3 in the $C d k n 1 b^{-/-}$mice that lack $\mathrm{p} 27^{\mathrm{Kip} 1}$ expression results in spontaneous development of T-cell leukemia (Wolfraim et al. 2004). In humans, deletions and germline mutations of the $C D K N 1 B$ gene occur frequently in pediatric ALL patients (Komuro et al. 1999; Takeuchi et al. 2002). Although the molecular mechanism remains to be elucidated, it is tempting to speculate that Smad3 deficiency might be at the basis of or contribute to the genesis of pediatric T-cell ALL.

The $\mathrm{t}(12 ; 21)(\mathrm{p} 13.2 ; \mathrm{q} 22.12)$ translocation generating the TEL-AML1, also known as ETV6-RUNX1, fusion oncoprotein is found in patients with childhood B cell precursor ALL (Swerdlow et al. 2008). Like AML1-EVI1 in AML patients, TEL-AML1 binds Smad3 and inhibits its ability to activate transcription of target genes (Ford et al. 2009). Murine early B cell progenitor cells expressing a TEL-AML1 transgene proliferate more slowly than parental cells but are more resistant to TGF- $\beta$-induced growth suppression (Ford et al. 2009). Further- more, whereas TEL-AML1 expression is insufficient for the development of leukemia, mice expressing a TEL-AML1 transgene bear a greatly expanded number of pre-pro-B cells (Ford et al. 2009). These results suggest that the inhibition of Smad3 function exerted by TEL-AML1 sustains the proliferation of preleukemic cells in childhood B cell precursor ALL patients.

Adult T-cell leukemia-lymphoma (ATL) is an aggressive and fatal T-cell neoplasm caused by infection with the human T-cell leukemia virus type-1 (HTLV-1) (Poiesz et al. 1980). ATL cells isolated from ATL patients secrete TGF- $\beta 1$, consistent with the ability of the HTLV-1 Tax oncoprotein to activate Tgfb1 transcription (Niitsu et al. 1988; Kim et al. 1990). However, Tax can associate with the MH2 domains of Smad2, Smad3, and Smad4, suggesting that Tax suppresses Smad functions (Lee et al. 2002). On the other hand, Tax induces JNK activity and c-Jun phosphorylation, which promotes the formation of a Smad3-c-Jun complex that blocks Smad3's DNA-binding capacity and ability to respond to TGF- $\beta$ (Arnulf et al. 2002). Thus, Tax may contribute to HTLV-1mediated leukemogenesis by suppressing TGF$\beta$-activated Smad activities in ATL patients.

\section{CONCLUSION}

In this review, we provided an overview of the multifunctional role of signaling by TGF- $\beta$ and related molecules in hematopoiesis and leukemogenesis. It has long been known that appropriate regulation of the TGF- $\beta$ signaling pathway in normal hematopoietic cells is crucial for hematopoietic homeostasis. In addition, the TGF- $\beta$-Smad signaling pathway may participate in molecular mechanisms that regulate normal HSC stemness in vivo. Finally, TGF- $\beta$ signaling contributes to the suppression of several types of leukemogenesis. Therefore, it is important to elucidate how leukemia-associated chromosomal alterations that abrogate TGF$\beta$-induced growth suppression are implicated in hematopoietic disorders. However, TGF- $\beta$ signaling is essential for survival, self-renewal, and resistance of CML stem cells to tyrosine kinase inhibition. Increased understanding of 
this signaling network in vivo may reveal novel avenues for controlling leukemic stem cell activity. Ultimately, new therapeutics developed from this expanded understanding may modulate these signaling pathways in vivo to improve the treatment of leukemia patients.

\section{REFERENCES}

* Reference is also in this collection.

Akada H, Yan D, Zou H, Fiering S, Hutchison RE, Mohi MG. 2010. Conditional expression of heterozygous or homozygous Jak2V617F from its endogenous promoter induces a polycythemia vera-like disease. Blood 115: 3589-3597.

Alarcón C, Zaromytidou AI, Xi Q, Gao S, Yu J, Fujisawa S, Barlas A, Miller AN, Manova-Todorova K, Macias MJ, et al. 2009. Nuclear CDKs drive Smad transcriptional activation and turnover in BMP and TGF- $\beta$ pathways. Cell 139: 757-769.

Araki M, Yang Y, Masubuchi N, Hironaka Y, Takei H, Morishita S, Mizukami Y, Kan S, Shirane S, Edahiro Y, et al. 2016. Activation of the thrombopoietin receptor by mutant calreticulin in CALR-mutant myeloproliferative neoplasms. Blood 127: 1307-1316.

Arber DA, Orazi A, Hasserjian R, Thiele J, Borowitz MJ, Le Beau MM, Bloomfield CD, Cazzola M, Vardiman JW. 2016. The 2016 revision to the World Health Organization classification of myeloid neoplasms and acute leukemia. Blood 127: 2391-2405.

Arnulf B, Villemain A, Nicot C, Mordelet E, Charneau P, Kersual J, Zermati Y, Mauviel A, Bazarbachi A, Hermine O. 2002. Human T-cell lymphotropic virus oncoprotein Tax represses TGF- $\beta 1$ signaling in human T cells via cJun activation: A potential mechanism of HTLV-I leukemogenesis. Blood 100: 4129-4138.

Arthur HM, Ure J, Smith AJ, Renforth G, Wilson DI, Torsney E, Charlton R, Parums DV, Jowett T, Marchuk DA, et al. 2000. Endoglin, an ancillary TGF $\beta$ receptor, is required for extraembryonic angiogenesis and plays a key role in heart development. Dev Biol 217: 42-53.

Bachegowda L, Gligich O, Mantzaris I, Schinke C, Wyville D, Carrillo T, Braunschweig I, Steidl U, Verma A. 2013. Signal transduction inhibitors in treatment of myelodysplastic syndromes. J Hematol Oncol 6: 50.

Bae E, Sato M, Kim RJ, Kwak MK, Naka K, Gim J, Kadota M, Tang B, Flanders KC, Kim TA, et al. 2014. Definition of Smad3 phosphorylation events that affect malignant and metastatic behaviors in breast cancer cells. Cancer Res 74: 6139-6149.

Barbara NP, Wrana JL, Letarte M. 1999. Endoglin is an accessory protein that interacts with the signaling receptor complex of multiple members of the transforming growth factor- $\beta$ superfamily. J Biol Chem 274: 584-594.

Beerman I, Seita J, Inlay MA, Weissman IL, Rossi DJ. 2014. Quiescent hematopoietic stem cells accumulate DNA damage during aging that is repaired upon entry into cell cycle. Cell Stem Cell 15: 37-50.
Benz C, Copley MR, Kent DG, Wohrer S, Cortes A, Aghaeepour N, Ma E, Mader H, Rowe K, Day C, et al. 2012. Hematopoietic stem cell subtypes expand differentially during development and display distinct lymphopoietic programs. Cell Stem Cell 10: 273-283.

Bhagat TD, Zhou L, Sokol L, Kessel R, Caceres G, Gundabolu K, Tamari R, Gordon S, Mantzaris I, Jodlowski T, et al. 2013. miR-21 mediates hematopoietic suppression in MDS by activating TGF- $\beta$ signaling. Blood 121: $2875-$ 2881.

Blank U, Karlsson S. 2011. The role of Smad signaling in hematopoiesis and translational hematology. Leukemia 25: $1379-1388$.

Blank U, Karlsson S. 2015. TGF- $\beta$ signaling in the control of hematopoietic stem cells. Blood 125: 3542-3550.

Blank U, Karlsson G, Moody JL, Utsugisawa T, Magnusson M, Singbrant S, Larsson J, Karlsson S. 2006. Smad7 promotes self-renewal of hematopoietic stem cells. Blood 108: 4246-4254.

Bruns I, Lucas D, Pinho S, Ahmed J, Lambert MP, Kunisaki Y, Scheiermann C, Schiff L, Poncz M, Bergman A, et al. 2014. Megakaryocytes regulate hematopoietic stem cell quiescence through CXCL4 secretion. Nat Med 20: $1315-1320$.

Capron C, Lacout C, Lecluse Y, Jalbert V, Chagraoui H, Charrier S, Galy A, Bennaceur-Griscelli A, Cramer-Borde E, Vainchenker W. 2010. A major role of TGF- $\beta 1$ in the homing capacities of murine hematopoietic stem cell/ progenitors. Blood 116: 1244-1253.

Certo MT, Ryu BY, Annis JE, Garibov M, Jarjour J, Rawlings DJ, Scharenberg AM. 2011. Tracking genome engineering outcome at individual DNA breakpoints. Nat Methods 8: 671-676.

Chagraoui H, Komura E, Tulliez M, Giraudier S, Vainchenker W, Wendling F. 2002. Prominent role of TGF$\beta 1$ in thrombopoietin-induced myelofibrosis in mice. Blood 100: 3495-3503.

Challen GA, Boles NC, Chambers SM, Goodell MA. 2010. Distinct hematopoietic stem cell subtypes are differentially regulated by TGF- $\beta 1$. Cell Stem Cell 6: 265-278.

Chen CZ, Li M, de Graaf D, Monti S, Gottgens B, Sanchez MJ, Lander ES, Golub TR, Green AR, Lodish HF. 2002. Identification of endoglin as a functional marker that defines long-term repopulating hematopoietic stem cells. Proc Natl Acad Sci 99: 15468-15473.

Cheng T, Rodrigues N, Shen H, Yang Y, Dombkowski D, Sykes M, Scadden DT. 2000. Hematopoietic stem cell quiescence maintained by $2^{\text {cip } 1 / \text { waf1 }}$. Science 287 : 1804-1808.

Cho RH, Sieburg HB, Müller-Sieburg CE. 2008. A new mechanism for the aging of hematopoietic stem cells: Aging changes the clonal composition of the stem cell compartment but not individual stem cells. Blood 111: 5553-5561.

Crisan M, Kartalaei PS, Vink C, Yamada-Inagawa T, Bollerot K, van IW, van der Linden R, de Sousa Lopes SM, Monteiro R, Mummery C, et al. 2015. BMP signalling differentially regulates distinct haematopoietic stem cell types. Nat Commun 6: 8040.

Datto MB, Frederick JP, Pan L, Borton AJ, Zhuang Y, Wang XF. 1999. Targeted disruption of Smad3 reveals an essen- 
tial role in transforming growth factor $\beta$-mediated signal transduction. Mol Cell Biol 19: 2495-2504.

de Klein A, van Kessel AG, Grosveld G, Bartram CR, Hagemeijer A, Bootsma D, Spurr NK, Heisterkamp N, Groffen J, Stephenson JR. 1982. A cellular oncogene is translocated to the Philadelphia chromosome in chronic myelocytic leukaemia. Nature 300: 765-767.

Derynck R, Miyazono K. 2007. TGF- $\beta$ and the TGF- $\beta$ family. In The TGF- $\beta$ family (ed. Derynck R, Miyazono K), pp. 29-43. Cold Spring Harbor Laboratory Press, Cold Spring Harbor, NY.

Derynck R, Zhang YE. 2003. Smad-dependent and Smadindependent pathways in TGF- $\beta$ family signalling. $\mathrm{Na}$ ture 425: 577-584.

Dong M, Blobe GC. 2006. Role of transforming growth factor- $\beta$ in hematologic malignancies. Blood 107: 4589-4596.

Eliasson P, Jonsson JI. 2010. The hematopoietic stem cell niche: Low in oxygen but a nice place to be. J Cell Physiol 222: $17-22$.

Epperly MW, Cao S, Goff J, Shields D, Zhou S, Glowacki J, Greenberger JS. 2005. Increased longevity of hematopoiesis in continuous bone marrow cultures and adipocytogenesis in marrow stromal cells derived from $\mathrm{Smad}^{-1-}$ mice. Exp Hematol 33: 353-362.

Eto Y, Tsuji T, Takezawa M, Takano S, Yokogawa Y, Shibai H. 1987. Purification and characterization of erythroid differentiation factor (EDF) isolated from human leukemia cell line THP-1. Biochem Biophys Res Commun 142: 1095-1103.

Fanconi G. 1967. Familial constitutional panmyelocytopathy, Fanconi's anemia (F.A.). I: Clinical aspects. Semin Hematol 4: 233-240.

Feng XH, Derynck R. 2005. Specificity and versatility in TGF- $\beta$ signaling through Smads. Annu Rev Cell Dev Biol 21: 659-693.

Feng XH, Liang YY, Liang M, Zhai W, Lin X. 2002. Direct interaction of c-Myc with Smad2 and Smad3 to inhibit TGF- $\beta$-mediated induction of the CDK inhibitor p15 ${ }^{\text {Ink4B }}$. Mol Cell 9: 133-143.

Flach J, Bakker ST, Mohrin M, Conroy PC, Pietras EM, Reynaud D, Alvarez S, Diolaiti ME, Ugarte F, Forsberg EC, et al. 2014. Replication stress is a potent driver of functional decline in ageing haematopoietic stem cells. Nature 512: 198-202.

Ford AM, Palmi C, Bueno C, Hong D, Cardus P, Knight D, Cazzaniga G, Enver T, Greaves M. 2009. The TEL-AML1 leukemia fusion gene dysregulates the TGF- $\beta$ pathway in early B lineage progenitor cells. J Clin Invest 119: 826836.

Gan B, Hu J, Jiang S, Liu Y, Sahin E, Zhuang L, FletcherSananikone E, Colla S, Wang YA, Chin L, et al. 2010. Lkb1 regulates quiescence and metabolic homeostasis of haematopoietic stem cells. Nature 468: 701-704.

Geiger H, de Haan G, Florian MC. 2013. The ageing haematopoietic stem cell compartment. Nat Rev Immunol 13: $376-389$.

Ghio M, Contini P, Negrini S, Boero S, Musso A, Poggi A. 2009. Soluble HLA-I-mediated secretion of TGF- $\beta 1$ by human NK cells and consequent down-regulation of anti-tumor cytolytic activity. Eur J Immunol 39: 34593468 .

Goyama S, Yamamoto G, Shimabe M, Sato T, Ichikawa M, Ogawa S, Chiba S, Kurokawa M. 2008. Evi-1 is a critical regulator for hematopoietic stem cells and transformed leukemic cells. Cell Stem Cell 3: 207-220.

Gurumurthy S, Xie SZ, Alagesan B, Kim J, Yusuf RZ, Saez B, Tzatsos A, Ozsolak F, Milos P, Ferrari F, et al. 2010. The Lkb1 metabolic sensor maintains haematopoietic stem cell survival. Nature 468: 659-663.

Ham SA, Kim HJ, Kang ES, Eun SY, Kim GH, Park MH, Woo IS, Chang KC, Lee JH, Seo HG. 2010. PPAR $\delta$ promotes wound healing by up-regulating TGF- $\beta 1$-dependent or -independent expression of extracellular matrix proteins. J Cell Mol Med 14: 1747-1759.

Ham SA, Hwang JS, Yoo T, Lee WJ, Paek KS, Oh JW, Park CK, Kim JH, Do JT, Seo HG. 2015. Ligand-activated PPAR $\delta$ upregulates $\alpha$-smooth muscle actin expression in human dermal fibroblasts: A potential role for PPAR $\delta$ in wound healing. J Dermatol Sci 80: 186-195.

* Hata A, Chen YG. 2016. TGF- $\beta$ signaling from receptors to Smads. Cold Spring Harb Perspect Biol 8: a022061.

* Heldin C-H, Moustakas A. 2016. Signaling receptors for TGF- $\beta$ family members. Cold Spring Harb Perspect Biol 8: a022053.

Horiguchi M, Ota M, Rifkin DB. 2012. Matrix control of transforming growth factor- $\beta$ function. $J$ Biochem 152: 321-329.

Huang HM, Chang TW, Liu JC. 2004. Basic fibroblast growth factor antagonizes activin A-mediated growth inhibition and hemoglobin synthesis in K562 cells by activating ERK1/2 and deactivating p38 MAP kinase. Biochem Biophys Res Commun 320: 1247-1252.

Huang HM, Chiou HY, Chang JL. 2006. Activin A induces erythroid gene expressions and inhibits mitogenic cytokine-mediated K562 colony formation by activating p38 MAPK. J Cell Biochem 98: 789-797.

Iancu-Rubin C, Mosoyan G, Wang J, Kraus T, Sung V, Hoffman R. 2013. Stromal cell-mediated inhibition of erythropoiesis can be attenuated by Sotatercept (ACE-011), an activin receptor type II ligand trap. Exp Hematol 41: 155166.e117.

Ikushima $\mathrm{H}$, Todo T, Ino $\mathrm{Y}$, Takahashi M, Miyazawa $\mathrm{K}$, Miyazono K. 2009. Autocrine TGF- $\beta$ signaling maintains tumorigenicity of glioma-initiating cells through Sry-related HMG-box factors. Cell Stem Cell 5: 504-514.

Ito K, Bernardi R, Morotti A, Matsuoka S, Saglio G, Ikeda Y, Rosenblatt J, Avigan DE, Teruya-Feldstein J, Pandolfi PP. 2008. PML targeting eradicates quiescent leukaemia-initiating cells. Nature 453: 1072-1078.

Ito K, Carracedo A, Weiss D, Arai F, Ala U, Avigan DE, Schafer ZT, Evans RM, Suda T, Lee CH, et al. 2012. A PML-PPAR- $\delta$ pathway for fatty acid oxidation regulates hematopoietic stem cell maintenance. Nat Med 18: 1350-1358.

Jacobsen SE, Keller JR, Ruscetti FW, Kondaiah P, Roberts AB, Falk LA. 1991. Bidirectional effects of transforming growth factor $\beta$ (TGF- $\beta$ ) on colony-stimulating factorinduced human myelopoiesis in vitro: Differential effects of distinct TGF- $\beta$ isoforms. Blood 78: 2239-2247. 
Jakubowiak A, Pouponnot C, Berguido F, Frank R, Mao S Massagué J, Nimer SD. 2000. Inhibition of the transforming growth factor $\beta 1$ signaling pathway by the AML1/ ETO leukemia-associated fusion protein. $J$ Biol Chem 275: 40282-40287.

Jenkins BJ, Grail D, Nheu T, Najdovska M, Wang B, Waring P, Inglese M, McLoughlin RM, Jones SA, Topley $\mathrm{N}$, et al. 2005a. Hyperactivation of Stat3 in gp130 mutant mice promotes gastric hyperproliferation and desensitizes TGF- $\beta$ signaling. Nat Med 11: 845-852.

Jenkins BJ, Roberts AW, Najdovska M, Grail D, Ernst M. 2005b. The threshold of gp130-dependent STAT3 signaling is critical for normal regulation of hematopoiesis. Blood 105: 3512-3520.

Kamaraju AK, Roberts AB. 2005. Role of Rho/ROCK and p38 MAP kinase pathways in transforming growth factor$\beta$-mediated Smad-dependent growth inhibition of human breast carcinoma cells in vivo. J Biol Chem 280: 1024-1036.

Karlsson G, Blank U, Moody JL, Ehinger M, Singbrant S, Deng CX, Karlsson S. 2007. Smad4 is critical for selfrenewal of hematopoietic stem cells. J Exp Med 204: 467-474.

Kim H, D'Andrea AD. 2012. Regulation of DNA cross-link repair by the Fanconi anemia/BRCA pathway. Genes Dev 26: $1393-1408$.

Kim SJ, Letterio J. 2003. Transforming growth factor- $\beta$ signaling in normal and malignant hematopoiesis. Leukemia 17: 1731-1737.

Kim SJ, Kehrl JH, Burton J, Tendler CL, Jeang KT, Danielpour D, Thevenin C, Kim KY, Sporn MB, Roberts AB. 1990. Transactivation of the transforming growth factor $\beta 1$ (TGF- $\beta 1$ ) gene by human T lymphotropic virus type 1 tax: A potential mechanism for the increased production of TGF- $\beta 1$ in adult T cell leukemia. J Exp Med 172: 121-129.

Komuro H, Valentine MB, Rubnitz JE, Saito M, Raimondi SC, Carroll AJ, Yi T, Sherr CJ, Look AT. 1999. p27 $7^{K I P 1}$ deletions in childhood acute lymphoblastic leukemia. Neoplasia 1: 253-261.

Kottemann MC, Smogorzewska A. 2013. Fanconi anaemia and the repair of Watson and Crick DNA crosslinks. $\mathrm{Na}$ ture 493: 356-363.

Krause DS, Fulzele K, Catic A, Sun CC, Dombkowski D, Hurley MP, Lezeau S, Attar E, Wu JY, Lin HY, et al. 2013. Differential regulation of myeloid leukemias by the bone marrow microenvironment. Nat Med 19: 1513-1517.

Kretzschmar M, Doody J, Timokhina I, Massagué J. 1999. A mechanism of repression of TGF $\beta$ / Smad signaling by oncogenic Ras. Genes Dev 13: 804-816.

Kulkarni AB, Huh CG, Becker D, Geiser A, Lyght M, Flanders KC, Roberts AB, Sporn MB, Ward JM, Karlsson S. 1993. Transforming growth factor $\beta 1$ null mutation in mice causes excessive inflammatory response and early death. Proc Natl Acad Sci 90: 770-774.

Kurokawa M, Mitani K, Imai Y, Ogawa S, Yazaki Y, Hirai H. 1998a. The $\mathrm{t}(3 ; 21)$ fusion product, AML1/Evi-1, interacts with Smad3 and blocks transforming growth factor$\beta$-mediated growth inhibition of myeloid cells. Blood 92: 4003-4012.
Kurokawa M, Mitani K, Irie K, Matsuyama T, Takahashi T, Chiba S, Yazaki Y, Matsumoto K, Hirai H. 1998b. The oncoprotein Evi-1 represses TGF- $\beta$ signalling by inhibiting Smad3. Nature 394: 92-96.

Langdon JM, Barkataki S, Berger AE, Cheadle C, Xue QL, Sung V, Roy CN. 2015. RAP-011, an activin receptor ligand trap, increases hemoglobin concentration in hepcidin transgenic mice. Am J Hematol 90: 8-14.

Langer JC, Henckaerts E, Orenstein J, Snoeck HW. 2004. Quantitative trait analysis reveals transforming growth factor- $\beta 2$ as a positive regulator of early hematopoietic progenitor and stem cell function. J Exp Med 199: 5-14.

Larsson J, Karlsson S. 2005. The role of Smad signaling in hematopoiesis. Oncogene 24: 5676-5692.

Larsson J, Goumans MJ, Sjostrand LJ, van Rooijen MA, Ward D, Leveen P, Xu X, ten Dijke P, Mummery CL, Karlsson S. 2001. Abnormal angiogenesis but intact hematopoietic potential in TGF- $\beta$ type I receptor-deficient mice. EMBO J 20: 1663-1673.

Larsson J, Blank U, Helgadottir H, Bjornsson JM, Ehinger M, Goumans MJ, Fan X, Leveen P, Karlsson S. 2003. TGF$\beta$ signaling-deficient hematopoietic stem cells have normal self-renewal and regenerative ability in vivo despite increased proliferative capacity in vitro. Blood 102: 31293135.

Larsson J, Blank U, Klintman J, Magnusson M, Karlsson S. 2005. Quiescence of hematopoietic stem cells and maintenance of the stem cell pool is not dependent on TGF- $\beta$ signaling in vivo. Exp Hematol 33: 592-596.

Lee DK, Kim BC, Brady JN, Jeang KT, Kim SJ. 2002. Human T-cell lymphotropic virus type 1 tax inhibits transforming growth factor- $\beta$ signaling by blocking the association of Smad proteins with Smad-binding element. J Biol Chem 277: 33766-33775.

Letterio JJ, Geiser AG, Kulkarni AB, Dang H, Kong L, Nakabayashi T, Mackall CL, Gress RE, Roberts AB. 1996. Autoimmunity associated with TGF- $\beta 1$-deficiency in mice is dependent on MHC class II antigen expression. J Clin Invest 98: 2109-2119.

Leveen P, Larsson J, Ehinger M, Cilio CM, Sundler M, Sjostrand LJ, Holmdahl R, Karlsson S. 2002. Induced disruption of the transforming growth factor $\beta$ type II receptor gene in mice causes a lethal inflammatory disorder that is transplantable. Blood 100: 560-568.

Li J, Spensberger D, Ahn JS, Anand S, Beer PA, Ghevaert C, Chen E, Forrai A, Scott LM, Ferreira R, et al. 2010. JAK2 V617F impairs hematopoietic stem cell function in a conditional knock-in mouse model of JAK2 V617F-positive essential thrombocythemia. Blood 116: 1528-1538.

Lin HK, Bergmann S, Pandolfi PP. 2004. Cytoplasmic PML function in TGF- $\beta$ signalling. Nature 431: 205-211.

Liu F. 2006. Smad3 phosphorylation by cyclin-dependent kinases. Cytokine Growth Factor Rev 17: 9-17.

Lo Celso C, Scadden DT. 2011. The haematopoietic stem cell niche at a glance. J Cell Sci 124: 3529-3535.

Maguer-Satta V, Bartholin L, Jeanpierre S, Ffrench M, Martel S, Magaud JP, Rimokh R. 2003. Regulation of human erythropoiesis by activin A, BMP2, and BMP4, members of the TGF $\beta$ family. Exp Cell Res 282: 110-120.

Marin D, Gabriel IH, Ahmad S, Foroni L, de Lavallade H, Clark R, O’Brien S, Sergeant R, Hedgley C, Milojkovic D, 
et al. 2012. KIR2DS1 genotype predicts for complete cytogenetic response and survival in newly diagnosed chronic myeloid leukemia patients treated with imatinib. Leukemia 26: 296-302.

Marty C, Lacout C, Martin A, Hasan S, Jacquot S, Birling MC, Vainchenker W, Villeval JL. 2010. Myeloproliferative neoplasm induced by constitutive expression of JAK2V617F in knock-in mice. Blood 116: 783-787.

Massagué J. 2000. How cells read TGF- $\beta$ signals. Nat Rev Mol Cell Biol 1: 169-178.

Massagué J. 2008. TGF $\beta$ in cancer. Cell 134: 215-230.

Massagué J. 2012. TGF $\beta$ signalling in context. Nat Rev Mol Cell Biol 13: 616-630.

Massagué J, Seoane J, Wotton D. 2005. Smad transcription factors. Genes Dev 19: 2783-2810.

Matsumoto A, Takeishi S, Kanie T, Susaki E, Onoyama I, Tateishi Y, Nakayama K, Nakayama KI. 2011. p57 is required for quiescence and maintenance of adult hematopoietic stem cells. Cell Stem Cell 9: 262-271.

Matsuoka S, Oike Y, Onoyama I, Iwama A, Arai F, Takubo K, Mashimo Y, Oguro H, Nitta E, Ito K, et al. 2008. Fbxw7 acts as a critical fail-safe against premature loss of hematopoietic stem cells and development of T-ALL. Genes Dev 22: 986-991.

Matsuura I, Denissova NG, Wang G, He D, Long J, Liu F. 2004. Cyclin-dependent kinases regulate the antiproliferative function of Smads. Nature 430: 226-231.

Matsuzaki K. 2013. Smad phospho-isoforms direct contextdependent TGF- $\beta$ signaling. Cytokine Growth Factor Rev 24: 385-399.

McAllister KA, Grogg KM, Johnson DW, Gallione CJ, Baldwin MA, Jackson CE, Helmbold EA, Markel DS, McKinnon WC, Murrell J, et al. 1994. Endoglin, a TGF- $\beta$ binding protein of endothelial cells, is the gene for hereditary haemorrhagic telangiectasia type 1. Nat Genet 8: 345351.

Millet C, Yamashita M, Heller M, Yu LR, Veenstra TD, Zhang YE. 2009. A negative feedback control of transforming growth factor- $\beta$ signaling by glycogen synthase kinase 3-mediated Smad3 linker phosphorylation at Ser204. J Biol Chem 284: 19808-19816.

Mitani K, Ogawa S, Tanaka T, Miyoshi H, Kurokawa M, Mano H, Yazaki Y, Ohki M, Hirai H. 1994. Generation of the AML1-EVI-1 fusion gene in the $\mathrm{t}(3 ; 21)(\mathrm{q} 26 ; \mathrm{q} 22)$ causes blastic crisis in chronic myelocytic leukemia. EMBO J 13: 504-510.

Miyamoto K, Araki KY, Naka K, Arai F, Takubo K, Yamazaki S, Matsuoka S, Miyamoto T, Ito K, Ohmura M, et al. 2007. Foxo3a is essential for maintenance of the hematopoietic stem cell pool. Cell Stem Cell 1: 101-112.

Mohrin M, Bourke E, Alexander D, Warr MR, Barry-Holson K, Le Beau MM, Morrison CG, Passegue E. 2010. Hematopoietic stem cell quiescence promotes error-prone DNA repair and mutagenesis. Cell Stem Cell 7: 174-185.

Møller GM, Frost V, Melo JV, Chantry A. 2007. Upregulation of the TGF $\beta$ signalling pathway by Bcr-Abl: Implications for haemopoietic cell growth and chronic myeloid leukaemia. FEBS Lett 581: 1329-1334.

Morén A, Raja E, Heldin CH, Moustakas A. 2011. Negative regulation of TGF $\beta$ signaling by the kinase LKB1 and the scaffolding protein LIP1. J Biol Chem 286: 341-353.
Morrison SJ, Scadden DT. 2014. The bone marrow niche for haematopoietic stem cells. Nature 505: 327-334.

Mullally A, Lane SW, Ball B, Megerdichian C, Okabe R, AlShahrour F, Paktinat M, Haydu JE, Housman E, Lord AM, et al. 2010. Physiological Jak2V617F expression causes a lethal myeloproliferative neoplasm with differential effects on hematopoietic stem and progenitor cells. Cancer Cell 17: 584-596.

Müller-Sieburg CE, Cho RH, Thoman M, Adkins B, Sieburg HB. 2002. Deterministic regulation of hematopoietic stem cell self-renewal and differentiation. Blood 100: 1302-1309.

Müller-Sieburg CE, Cho RH, Karlsson L, Huang JF, Sieburg HB. 2004. Myeloid-biased hematopoietic stem cells have extensive self-renewal capacity but generate diminished lymphoid progeny with impaired IL-7 responsiveness. Blood 103: 4111-4118.

Naka K, Hirao A. 2013. TGF- $\beta$ signaling in leukemogenesis. In TGF- $\beta$ signaling in human disease (ed. Moustakas A, Miyazawa K), pp. 189-207. Springer, Tokyo.

Naka K, Hoshii T, Muraguchi T, Tadokoro Y, Ooshio T, Kondo Y, Nakao S, Motoyama N, Hirao A. 2010. TGF$\beta$-FOXO signalling maintains leukaemia-initiating cells in chronic myeloid leukaemia. Nature 463: 676-680.

Naka K, Jomen Y, Ishihara K, Kim J, Ishimoto T, Bae EJ, Mohney RP, Stirdivant SM, Oshima H, Oshima M, et al. 2015. Dipeptide species regulate p38MAPK-Smad3 signalling to maintain chronic myelogenous leukaemia stem cells. Nat Commun 6: 8039.

Naka K, Ishihara K, Jomen Y, Jin CH, Kim DH, Gu YK, Jeong ES, Li S, Krause DS, Kim DW, et al. 2016. The novel oral TGF- $\beta$ signaling inhibitor EW-7197 eradicates chronic myelogenous leukemia-initiating cells. Cancer Sci 107: 140-148.

Nakada D, Saunders TL, Morrison SJ. 2010. Lkb1 regulates cell cycle and energy metabolism in haematopoietic stem cells. Nature 468: 653-658.

* Namwanje M, Brown CW. 2016. Activins and inhibins: Roles in development, physiology, and disease. Cold Spring Harb Perspect Biol 8: a021881.

Niitsu Y, Urushizaki Y, Koshida Y, Terui K, Mahara K, Kohgo Y, Urushizaki I. 1988. Expression of TGF- $\beta$ gene in adult T cell leukemia. Blood 71: 263-266.

Nomura M, Li E. 1998. Smad2 role in mesoderm formation, left-right patterning and craniofacial development. $\mathrm{Na}$ ture 393: $786-790$

Ogawa S, Kurokawa M, Tanaka T, Tanaka K, Hangaishi A, Mitani K, Kamada N, Yazaki Y, Hirai H. 1996. Increased Evi-1 expression is frequently observed in blastic crisis of chronic myelocytic leukemia. Leukemia 10: 788-794.

O'Hare T, Zabriskie MS, Eiring AM, Deininger MW. 2012. Pushing the limits of targeted therapy in chronic myeloid leukaemia. Nat Rev Cancer 12: 513-526.

Ohta M, Greenberger JS, Anklesaria P, Bassols A, Massagué J. 1987. Two forms of transforming growth factor- $\beta$ distinguished by multipotential haematopoietic progenitor cells. Nature 329: 539-541.

Orkin SH, Zon LI. 2008. Hematopoiesis: An evolving paradigm for stem cell biology. Cell 132: 631-644. 
Oshima M, Oshima H, Taketo MM. 1996. TGF- $\beta$ receptor type II deficiency results in defects of yolk sac hematopoiesis and vasculogenesis. Dev Biol 179: 297-302.

Oshimori N, Oristian D, Fuchs E. 2015. TGF- $\beta$ promotes heterogeneity and drug resistance in squamous cell carcinoma. Cell 160: 963-976.

Ottmann OG, Pelus LM. 1988. Differential proliferative effects of transforming growth factor- $\beta$ on human hematopoietic progenitor cells. J Immunol 140: 2661-2665.

Pellicano F, Scott MT, Helgason GV, Hopcroft LE, Allan EK, Aspinall-O’Dea M, Copland M, Pierce A, Huntly BJ, Whetton AD, et al. 2014. The anti-proliferative activity of kinase inhibitors in chronic myeloid leukaemia cells is mediated by FOXO transcription factors. Stem Cells 32: 2324-2337.

Peñuelas S, Anido J, Prieto-Sánchez RM, Folch G, Barba I, Cuartas I, García-Dorado D, Poca MA, Sahuquillo J, Baselga J, et al. 2009. TGF- $\beta$ increases glioma-initiating cell self-renewal through the induction of LIF in human glioblastoma. Cancer Cell 15: 315-327.

Pietras EM, Warr MR, Passegué E. 2011. Cell cycle regulation in hematopoietic stem cells. J Cell Biol 195: 709-720.

Pietras EM, Reynaud D, Kang YA, Carlin D, Calero-Nieto FJ, Leavitt AD, Stuart JM, Göttgens B, Passegué E. 2015. Functionally distinct subsets of lineage-biased multipotent progenitors control blood production in normal and regenerative conditions. Cell Stem Cell 17: 35-46.

Poiesz BJ, Ruscetti FW, Gazdar AF, Bunn PA, Minna JD, Gallo RC. 1980. Detection and isolation of type C retrovirus particles from fresh and cultured lymphocytes of a patient with cutaneous T-cell lymphoma. Proc Natl Acad Sci 77: 7415-7419.

Quéré R, Saint-Paul L, Carmignac V, Martin RZ, Chrétien ML, Largeot A, Hammann A, Pais de Barros JP, Bastie JN Delva L. 2014. Tifl $\gamma$ regulates the TGF- $\beta 1$ receptor and promotes physiological aging of hematopoietic stem cells. Proc Natl Acad Sci 111: 10592-10597.

Raftopoulos H, Laadem A, Hesketh PJ, Goldschmidt J, Gabrail N, Osborne C, Ali M, Sherman ML, Wang D, Glaspy JA, et al. 2016. Sotatercept (ACE-011) for the treatment of chemotherapy-induced anemia in patients with metastatic breast cancer or advanced or metastatic solid tumors treated with platinum-based chemotherapeutic regimens: Results from two phase 2 studies. Support Care Cancer 24: 1517-1525.

Reavie L, Della Gatta G, Crusio K, Aranda-Orgilles B, Buckley SM, Thompson B, Lee E, Gao J, Bredemeyer AL, Helmink BA, et al. 2010. Regulation of hematopoietic stem cell differentiation by a single ubiquitin ligase-substrate complex. Nat Immunol 11: 207-215.

Ren R. 2005. Mechanisms of BCR-ABL in the pathogenesis of chronic myelogenous leukaemia. Nat Rev Cancer 5: $172-183$.

Reya T, Clevers H. 2005. Wnt signalling in stem cells and cancer. Nature 434: 843-850.

Reya T, Morrison SJ, Clarke MF, Weissman IL. 2001. Stem cells, cancer, and cancer stem cells. Nature 414: 105-111.

Reya T, Duncan AW, Ailles L, Domen J, Scherer DC, Willert K, Hintz L, Nusse R, Weissman IL. 2003. A role for Wnt signalling in self-renewal of haematopoietic stem cells. Nature 423: 409-414.
* Robertson IB, Rifkin DB. 2016. Regulation of the bioavailability of TGF- $\beta$ and TGF- $\beta$-related proteins. Cold Spring Harb Perspect Biol 8: a021907.

Rörby E, Högerström MN, Blank U, Karlsson G, Karlsson S. 2012. Human hematopoietic stem/progenitor cells overexpressing Smad4 exhibit impaired reconstitution potential in vivo. Blood 120: 4343-4351.

Rossi DJ, Bryder D, Seita J, Nussenzweig A, Hoeijmakers J, Weissman IL. 2007. Deficiencies in DNA damage repair limit the function of haematopoietic stem cells with age. Nature 447: 725-729.

Rowley JD. 1973. Letter: A new consistent chromosomal abnormality in chronic myelogenous leukaemia identified by quinacrine fluorescence and Giemsa staining. $\mathrm{Na}$ ture 243: 290-293.

Rübe CE, Fricke A, Widmann TA, Fürst T, Madry H, Pfreundschuh M, Rübe C. 2011. Accumulation of DNA damage in hematopoietic stem and progenitor cells during human aging. PLoS ONE 6: e17487.

Sato T, Goyama S, Kataoka K, Nasu R, Tsuruta-Kishino T, Kagoya Y, Nukina A, Kumagai K, Kubota N, Nakagawa M, et al. 2014. Evil defines leukemia-initiating capacity and tyrosine kinase inhibitor resistance in chronic myeloid leukemia. Oncogene 33: 5028-5038.

Sawyer SL, Tian L, Kahkonen M, Schwartzentruber J, Kircher M, Majewski J, Dyment DA, Innes AM, Boycott KM, Moreau LA, et al. 2015. Biallelic mutations in BRCA1 cause a new Fanconi anemia subtype. Cancer Discov 5: 135-142.

Scandura JM, Boccuni P, Massague J, Nimer SD. 2004. Transforming growth factor $\beta$-induced cell cycle arrest of human hematopoietic cells requires p5 $7^{\text {KIP2 }}$ up-regulation. Proc Natl Acad Sci 101: 15231-15236.

Scheller M, Huelsken J, Rosenbauer F, Taketo MM, Birchmeier W, Tenen DG, Leutz A. 2006. Hematopoietic stem cell and multilineage defects generated by constitutive $\beta$ catenin activation. Nat Immunol 7: 1037-1047.

Schroeder T. 2010. Hematopoietic stem cell heterogeneity: Subtypes, not unpredictable behavior. Cell Stem Cell 6: 203-207.

Seoane J, Le HV, Shen L, Anderson SA, Massagué J. 2004. Integration of Smad and forkhead pathways in the control of neuroepithelial and glioblastoma cell proliferation. Cell 117: 211-223.

Shackelford DB, Shaw RJ. 2009. The LKB1-AMPK pathway: Metabolism and growth control in tumour suppression. Nat Rev Cancer 9: 563-575.

Shide K, Shimoda HK, Kumano T, Karube K, Kameda T, Takenaka K, Oku S, Abe H, Katayose KS, Kubuki Y, et al. 2008. Development of ET, primary myelofibrosis and PV in mice expressing JAK2 V617F. Leukemia 22: 87-95.

Shiozaki M, Sakai R, Tabuchi M, Eto Y, Kosaka M, Shibai H. 1989. In vivo treatment with erythroid differentiation factor (EDF/activin A) increases erythroid precursors (CFU-E and BFU-E) in mice. Biochem Biophys Res Commun 165: 1155-1161.

Shull MM, Ormsby I, Kier AB, Pawlowski S, Diebold RJ, Yin M, Allen R, Sidman C, Proetzel G, Calvin D, et al. 1992. Targeted disruption of the mouse transforming growth factor- $\beta 1$ gene results in multifocal inflammatory disease. Nature 359: 693-699. 
Sieburg HB, Cho RH, Dykstra B, Uchida N, Eaves CJ, Müller-Sieburg CE. 2006. The hematopoietic stem compartment consists of a limited number of discrete stem cell subsets. Blood 107: 2311-2316.

Singbrant S, Moody JL, Blank U, Karlsson G, Umans L, Zwijsen A, Karlsson S. 2006. Smad5 is dispensable for adult murine hematopoiesis. Blood 108: 3707-3712.

Singbrant S, Karlsson G, Ehinger M, Olsson K, Jaako P, Miharada K, Stadtfeld M, Graf T, Karlsson S. 2010. Canonical BMP signaling is dispensable for hematopoietic stem cell function in both adult and fetal liver hematopoiesis, but essential to preserve colon architecture. Blood 115: 4689-4698.

Sirard C, de la Pompa JL, Elia A, Itie A, Mirtsos C, Cheung A, Hahn S, Wakeham A, Schwartz L, Kern SE, et al. 1998. The tumor suppressor gene Smad4/Dpc4 is required for gastrulation and later for anterior development of the mouse embryo. Genes Dev 12: 107-119.

Söderberg SS, Karlsson G, Karlsson S. 2009. Complex and context dependent regulation of hematopoiesis by TGF$\beta$ superfamily signaling. Ann NY Acad Sci 1176: 55-69.

Soma T, Yu JM, Dunbar CE. 1996. Maintenance of murine long-term repopulating stem cells in ex vivo culture is affected by modulation of transforming growth factor$\beta$ but not macrophage inflammatory protein-1 $\alpha$ activities. Blood 87: 4561-4567.

Suda T, Arai F, Hirao A. 2005. Hematopoietic stem cells and their niche. Trends Immunol 26: 426-433.

Sun D, Luo M, Jeong M, Rodriguez B, Xia Z, Hannah R, Wang H, Le T, Faull KF, Chen R, et al. 2014. Epigenomic profiling of young and aged HSCs reveals concerted changes during aging that reinforce self-renewal. Cell Stem Cell 14: 673-688.

Suragani RN, Cadena SM, Cawley SM, Sako D, Mitchell D, Li R, Davies MV, Alexander MJ, Devine M, Loveday KS, et al. 2014. Transforming growth factor- $\beta$ superfamily ligand trap ACE- 536 corrects anemia by promoting latestage erythropoiesis. Nat Med 20: 408-414.

Swerdlow SH, Campo E, Harris NL, et al. 2008. WHO classification of tumours of haematopoietic and lymphoid tissues. IARC, Lyon, France.

Takeuchi C, Takeuchi S, Ikezoe T, Bartram CR, Taguchi H, Koeffler HP. 2002. Germline mutation of the p27/Kip1 gene in childhood acute lymphoblastic leukemia. Leukemia 16: 956-958.

Tefferi A, Pardanani A. 2015. Myeloproliferative neoplasms: A contemporary review. JAMA Oncol 1: 97-105.

Thompson BJ, Jankovic V, Gao J, Buonamici S, Vest A, Lee JM, Zavadil J, Nimer SD, Aifantis I. 2008. Control of hematopoietic stem cell quiescence by the E3 ubiquitin ligase Fbw7. J Exp Med 205: 1395-1408.

Tiedt R, Hao-Shen H, Sobas MA, Looser R, Dirnhofer S, Schwaller J, Skoda RC. 2008. Ratio of mutant JAK2V617F to wild-type Jak2 determines the MPD phenotypes in transgenic mice. Blood 111: 3931-3940.

Tothova Z, Kollipara R, Huntly BJ, Lee BH, Castrillon DH, Cullen DE, McDowell EP, Lazo-Kallanian S, Williams IR, Sears C, et al. 2007. FoxOs are critical mediators of hematopoietic stem cell resistance to physiologic oxidative stress. Cell 128: 325-339.
Ulloa L, Doody J, Massagué J. 1999. Inhibition of transforming growth factor- $\beta / S M A D$ signalling by the interferon$\gamma /$ STAT pathway. Nature 397: 710-713.

Vainchenker W, Constantinescu SN. 2013. JAK/STAT signaling in hematological malignancies. Oncogene 32: 26012613

Verovskaya E, Broekhuis MJ, Zwart E, Ritsema M, van Os R, de Haan G, Bystrykh LV. 2013. Heterogeneity of young and aged murine hematopoietic stem cells revealed by quantitative clonal analysis using cellular barcoding. Blood 122: 523-532.

Wakefield LM, Roberts AB. 2002. TGF- $\beta$ signaling: Positive and negative effects on tumorigenesis. Curr Opin Genet Dev 12: $22-29$.

Waldrip WR, Bikoff EK, Hoodless PA, Wrana JL, Robertson EJ. 1998. Smad2 signaling in extraembryonic tissues determines anterior-posterior polarity of the early mouse embryo. Cell 92: 797-808.

Wang LD, Wagers AJ. 2011. Dynamic niches in the origination and differentiation of haematopoietic stem cells. Nat Rev Mol Cell Biol 12: 643-655.

Wang G, Matsuura I, He D, Liu F. 2009. Transforming growth factor- $\beta$-inducible phosphorylation of Smad3.J Biol Chem 284: 9663-9673.

Wang L, Gural A, Sun XJ, Zhao X, Perna F, Huang G, Hatlen MA, Vu L, Liu F, Xu H, et al. 2011. The leukemogenicity of AML1-ETO is dependent on site-specific lysine acetylation. Science 333: 765-769.

Warr MR, Binnewies M, Flach J, Reynaud D, Garg T, Malhotra R, Debnath J, Passegué E. 2013. FOXO3A directs a protective autophagy program in haematopoietic stem cells. Nature 494: 323-327.

Weinstein M, Yang X, Li C, Xu X, Gotay J, Deng CX. 1998. Failure of egg cylinder elongation and mesoderm induction in mouse embryos lacking the tumor suppressor smad2. Proc Natl Acad Sci 95: 9378-9383.

Wilson A, Murphy MJ, Oskarsson T, Kaloulis K, Bettess MD, Oser GM, Pasche AC, Knabenhans C, Macdonald HR, Trumpp A. 2004. c-Myc controls the balance between hematopoietic stem cell self-renewal and differentiation. Genes Dev 18: 2747-2763.

Wolfraim LA, Fernandez TM, Mamura M, Fuller WL, Kumar R, Cole DE, Byfield S, Felici A, Flanders KC, Walz TM, et al. 2004. Loss of Smad3 in acute T-cell lymphoblastic leukemia. N Engl J Med 351: 552-559.

Wrighton KH, Lin X, Feng XH. 2009. Phospho-control of TGF- $\beta$ superfamily signaling. Cell Res 19: 8-20.

Xing S, Wanting TH, Zhao W, Ma J, Wang S, Xu X, Li Q, Fu $\mathrm{X}, \mathrm{Xu} \mathrm{M}$, Zhao ZJ. 2008. Transgenic expression of $\mathrm{JAK} 2^{\mathrm{V} 617 \mathrm{~F}}$ causes myeloproliferative disorders in mice. Blood 111: 5109-5117.

Xu J, Lamouille S, Derynck R. 2009. TGF- $\beta$-induced epithelial to mesenchymal transition. Cell Res 19: 156-172.

Yalcin S, Zhang X, Luciano JP, Mungamuri SK, Marinkovic D, Vercherat C, Sarkar A, Grisotto M, Taneja R, Ghaffari S. 2008. Foxo3 is essential for the regulation of ataxia telangiectasia mutated and oxidative stress-mediated homeostasis of hematopoietic stem cells. J Biol Chem 283: 25692-25705.

Yamazaki S, Iwama A, Takayanagi S, Morita Y, Eto K, Ema H, Nakauchi H. 2006. Cytokine signals modulated via lipid 
rafts mimic niche signals and induce hibernation in hematopoietic stem cells. EMBO J 25: 3515-3523.

Yamazaki S, Iwama A, Takayanagi SI, Eto K, Ema H, Nakauchi H. 2009. TGF- $\beta$ as a candidate bone marrow niche signal to induce hematopoietic stem cell hibernation. Blood 113: 1250-1256.

Yamazaki S, Ema H, Karlsson G, Yamaguchi T, Miyoshi H, Shioda S, Taketo MM, Karlsson S, Iwama A, Nakauchi H. 2011. Nonmyelinating Schwann cells maintain hematopoietic stem cell hibernation in the bone marrow niche. Cell 147: 1146-1158.

Yang X, Li C, Xu X, Deng C. 1998. The tumor suppressor SMAD4/DPC4 is essential for epiblast proliferation and mesoderm induction in mice. Proc Natl Acad Sci 95: 3667-3672.

Yang X, Letterio JJ, Lechleider RJ, Chen L, Hayman R, Gu H, Roberts AB, Deng C. 1999. Targeted disruption of SMAD3 results in impaired mucosal immunity and diminished T cell responsiveness to TGF- $\beta$. EMBO J 18: $1280-1291$.

Yaswen L, Kulkarni AB, Fredrickson T, Mittleman B, Schiffman R, Payne S, Longenecker G, Mozes E, Karlsson S. 1996. Autoimmune manifestations in the transforming growth factor- $\beta 1$ knockout mouse. Blood 87: 1439 1445.

Yokota A, Kimura S, Tanaka R, Takeuchi M, Yao H, Sakai K, Nagao R, Kuroda J, Kamitsuji Y, Kawata E, et al. 2010. Osteoclasts are involved in the maintenance of dormant leukemic cells. Leuk Res 34: 793-799.

Yu J, Shao LE, Lemas V, Yu AL, Vaughan J, Rivier J, Vale W. 1987. Importance of FSH-releasing protein and inhibin in erythrodifferentiation. Nature 330: 765-767.

Yuasa H, Oike Y, Iwama A, Nishikata I, Sugiyama D, Perkins A, Mucenski ML, Suda T, Morishita K. 2005. Oncogenic transcription factor Evil regulates hematopoietic stem cell proliferation through GATA-2 expression. EMBO 24: 1976-1987.

Zhang J, Niu C, Ye L, Huang H, He X, Tong WG, Ross J, Haug J, Johnson T, Feng JQ, et al. 2003. Identification of
TGF- $\beta$ and Related Signaling in Hematopoiesis

the haematopoietic stem cell niche and control of the niche size. Nature 425: 836-841.

Zhang H, Kozono DE, O'Connor KW, Vidal-Cardenas S, Rousseau A, Hamilton A, Moreau L, Gaudiano EF, Greenberger J, Bagby G, et al. 2016. TGF- $\beta$ inhibition rescues hematopoietic stem cell defects and bone marrow failure in Fanconi anemia. Cell Stem Cell 18: 668-681.

Zhao C, Blum J, Chen A, Kwon HY, Jung SH, Cook JM, Lagoo A, Reya T. 2007. Loss of $\beta$-catenin impairs the renewal of normal and CML stem cells in vivo. Cancer Cell 12: 528-541.

Zhao M, Perry JM, Marshall H, Venkatraman A, Qian P, He XC, Ahamed J, Li L. 2014. Megakaryocytes maintain homeostatic quiescence and promote post-injury regeneration of hematopoietic stem cells. Nat Med 20: 13211326.

Zhou L, Nguyen AN, Sohal D, Ying Ma J, Pahanish P, Gundabolu K, Hayman J, Chubak A, Mo Y, Bhagat TD, et al. 2008. Inhibition of the TGF- $\beta$ receptor I kinase promotes hematopoiesis in MDS. Blood 112: 3434-3443.

Zhou L, McMahon C, Bhagat T, Alencar C, Yu Y, Fazzari M, Sohal D, Heuck C, Gundabolu K, Ng C, et al. 2011. Reduced SMAD7 leads to overactivation of TGF- $\beta$ signaling in MDS that can be reversed by a specific inhibitor of TGF- $\beta$ receptor I kinase. Cancer Res 71: 955-963.

Zhou B, Liu Y, Kahn M, Ann DK, Han A, Wang H, Nguyen C, Flodby P, Zhong Q, Krishnaveni MS, et al. 2012. Interactions between $\beta$-catenin and transforming growth factor- $\beta$ signaling pathways mediate epithelial-mesenchymal transition and are dependent on the transcriptional co-activator cAMP-response element-binding protein (CREB)-binding protein (CBP). J Biol Chem 287: 7026-7038.

Zon LI. 2008. Intrinsic and extrinsic control of haematopoietic stem-cell self-renewal. Nature 453: 306-313.

Zou P, Yoshihara H, Hosokawa K, Tai I, Shinmyozu K, Tsukahara F, Maru Y, Nakayama K, Nakayama KI, Suda T. 2011. p5 $7^{\mathrm{Kip} 2}$ and $\mathrm{p} 27^{\mathrm{Kip} 1}$ cooperate to maintain hematopoietic stem cell quiescence through interactions with Hsc70. Cell Stem Cell 9: 247-261. 


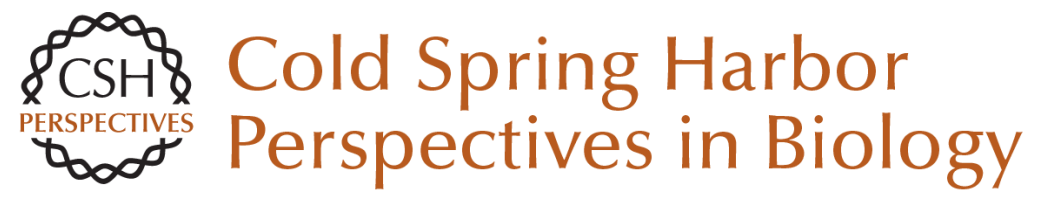

\section{Regulation of Hematopoiesis and Hematological Disease by TGF- $\beta$ Family Signaling Molecules}

Kazuhito Naka and Atsushi Hirao

Cold Spring Harb Perspect Biol 2017; doi: 10.1101/cshperspect.a027987 originally published online February 13, 2017

Subject Collection The Biology of the TGF-\&\#946; Family

TGF- $\beta$ Family Signaling in Early Vertebrate

Development

Joseph Zinski, Benjamin Tajer and Mary C. Mullins

Bone Morphogenetic Protein-Based Therapeutic Approaches

Jonathan W. Lowery and Vicki Rosen

TGF- $\beta$ Family Signaling in Ductal Differentiation and Branching Morphogenesis

Kaoru Kahata, Varun Maturi and Aristidis

Moustakas

TGF- $\beta$ Signaling in Control of Cardiovascular

Function

Marie-José Goumans and Peter ten Dijke

TGF- $\beta$ Family Signaling in Tumor Suppression and Cancer Progression Joan Seoane and Roger R. Gomis

Targeting TGF- $\beta$ Signaling for Therapeutic Gain Rosemary J. Akhurst

Regulation of Hematopoiesis and Hematological Disease by TGF- $\beta$ Family Signaling Molecules Kazuhito Naka and Atsushi Hirao
TGF- $\beta$ Family Signaling in Mesenchymal

Differentiation

Ingo Grafe, Stefanie Alexander, Jonathan $R$.

Peterson, et al.

TGF- $\beta 1$ Signaling and Tissue Fibrosis

Kevin K. Kim, Dean Sheppard and Harold A.

Chapman

Bone Morphogenetic Proteins in Vascular

Homeostasis and Disease

Marie-José Goumans, An Zwijsen, Peter ten Dijke, et al.

TGF- $\beta$ Family Signaling in Epithelial

Differentiation and Epithelial-Mesenchymal

Transition Kaoru Kahata, Mahsa Shahidi Dadras and Aristidis Moustakas

TGF- $\beta$ Family Signaling in Connective Tissue and

Skeletal Diseases

Elena Gallo MacFarlane, Julia Haupt, Harry C.

Dietz, et al.

The TGF- $\beta$ Family in the Reproductive Tract

Diana Monsivais, Martin M. Matzuk and Stephanie A. Pangas

TGF- $\beta$ Family Signaling in Drosophila Ambuj Upadhyay, Lindsay Moss-Taylor, Myung-Jun Kim, et al.

For additional articles in this collection, see http://cshperspectives.cshlp.org/cgi/collection/

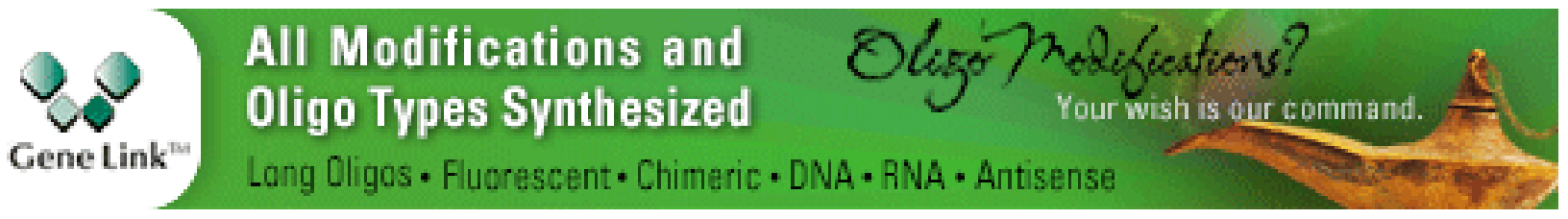

Copyright @ 2017 Cold Spring Harbor Laboratory Press; all rights reserved 
TGF- $\beta$ Family Signaling in Neural and Neuronal Differentiation, Development, and Function Emily A. Meyers and John A. Kessler
Signaling Cross Talk between TGF- $\beta /$ Smad and Other Signaling Pathways Kunxin LuO

For additional articles in this collection, see http://cshperspectives.cshlp.org/cgi/collection/

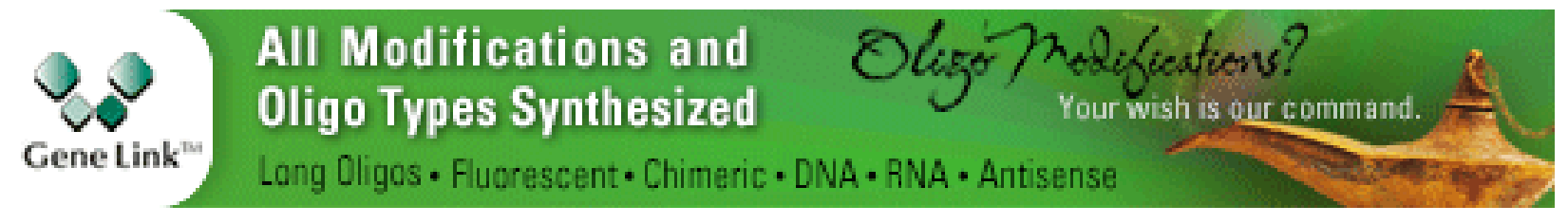

Copyright @ 2017 Cold Spring Harbor Laboratory Press; all rights reserved 